Journal of the Marine

Biological Association of the

United Kingdom

cambridge.org/mbi

\section{Review}

Cite this article: Rainbow PS (2020). Miningcontaminated estuaries of Cornwall - field research laboratories for trace metal ecotoxicology. Journal of the Marine Biological Association of the United Kingdom 100, 195-210. https://doi.org/10.1017/ S002531541900122X

Received: 29 April 2019

Revised: 6 December 2019

Accepted: 19 December 2019

First published online: 10 January 2020

\section{Key words:}

Comparative ecophysiology; ecotoxicology; Gannel; Hayle; Restronguet Creek; Tamar; West Looe

\section{Author for correspondence:}

Philip S. Rainbow, E-mail:

philipstephenrainbow@gmail.com

\title{
Mining-contaminated estuaries of Cornwall - field research laboratories for trace metal ecotoxicology
}

\author{
Philip S. Rainbow (1)
}

Department of Life Sciences, Natural History Museum, Cromwell Road, London SW7 5BD, UK

\begin{abstract}
A century or so after the cessation of almost all mining in Cornwall, certain estuaries still have extremely high sediment concentrations of toxic trace metals, particularly copper and arsenic, but also lead and zinc. These high trace metal loadings in the sediments are to a large degree bioavailable to the local infauna, especially sediment-ingesting invertebrates. Some sediment trace metal bioavailabilities are so high as to be of ecotoxicological concern, with deleterious effects on the local biota at levels of biological organization up to and including changed community structure. The estuaries of interest here are those of the Rivers Carnon (Restronguet Creek), Tamar (and Tavy), Gannel, West Looe and Hayle. These estuaries are especially attractive field sites for comparative trace metal ecophysiology and ecotoxicology research for they lack the confounding presence of other anthropogenic contaminants inevitably present in most estuaries in the developed world. The estuaries also offer a range of combinations of different trace metals and a comparative gradient of sediment bioavailabilities of these trace metals.
\end{abstract}

\section{Introduction}

Mention of Cornwall today raises a vision of a county with holiday beaches and picturesque villages snuggling in coves along a spectacular rugged coast, the home ports of flotillas of small fishing boats. But 'twas not ever thus. Cornwall in the 19th century and earlier was a mining region of national and international importance, a major player in the world production of trace metals such as tin and copper, and the metalloid arsenic (included here for convenience as a trace metal). Then, throw in lead, zinc, iron and historically some silver, as well as much lower amounts of tungsten, manganese, antimony, cobalt, nickel and molybdenum (Dines, 1969; Rainbow, 2018). The mining of the ores of these metals, all potentially toxic, inevitably led to deleterious environmental impacts on local terrestrial habitats, with serious knock-on effects in the streams and rivers draining these mining areas and ultimately their estuaries (Rainbow, 2018).

This review highlights the point that several of these Cornish estuaries still today contain sediments derived from mining activities with extremely high concentrations of toxic trace metals. Much of these sediment-associated metals are bioavailable to estuarine biota such as burrowing invertebrates ingesting the sediment as a food source and are of ecotoxicological significance today, decades or more than a century after the cessation of mining in their catchment. These Cornish estuaries are the outflow points of rivers that are very short, barely tens of kilometres long, typically draining catchments without large conurbations or regions of other industrial development. So, unlike most estuaries today, these metal-contaminated estuaries of Cornwall all but lack the usual associated presence of so many other toxic contaminants resulting from today's industrialized society - for example organic contaminants such as hydrocarbons in oil, organochlorines (e.g. PCBs) and their ilk. As a result these trace metal-contaminated estuaries provide ideal comparative field sites to study the ecotoxicological effects of high trace metal loadings in estuaries without the confounding effects of these other contaminants.

(c) Marine Biological Association of the United Kingdom 2020

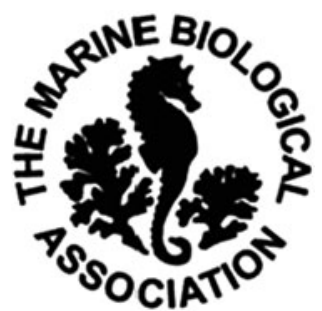

\section{Mining in south-west Britain}

In Britain, metal ores typically occur in mineral veins in areas where, in the geological past, a mass of igneous granite has been intruded into overlying sedimentary rock strata, causing fracturing in these strata (Dines, 1969). Hot hydrothermal fluids containing metal salts enter the fractures from below during the intrusion. On cooling these metal salts deposit as veins of metal ores (Dines, 1969). There is an order of deposition of the different ores as temperatures cool, so that they take up a zoned arrangement with depth - tin deepest, then copper, lead, zinc (these two often together) and finally iron in ascending order (Perkins, 1972). Ores of secondary metals are associated with these primary metal ores - tungsten in the tin zone, arsenic in the copper zone, and silver in the lead/zinc zone. The idealized vertical succession of the metal ores may be displaced laterally and often the full vertical succession of metal ore zones will not be present. Furthermore there may be secondary weathering of the metal salts 
first deposited, for example the oxidation of metal sulphides to oxides and, particularly in the presence of limestone, carbonates.

In what is now south-west England there was a major mountain building event in the Carboniferous and early Permian, and granite masses were intruded into overlying sedimentary rock strata (sandstones, mudstones and siltstones) which had typically been laid down in the Devonian period (Dines, 1969). In south-west England today, there are five major granite intrusions protruding through the Palaeozoic strata - those of Land's End, Carnmenellis (the area of west Cornwall between Redruth, Helston and Penryn), St Austell Moor, Bodmin Moor and Dartmoor (Dines, 1969). The veins containing metal ores are usually on the margins of the granite intrusions, with tin and copper veins expected closer to the edge of the granite, and lead and zinc veins potentially further away (Dines, 1969). Today the granite masses are typically exposed above the Palaeozoic rocks into which they were intruded, for weathering has stripped off much of any remaining cover.

Back in the Bronze Age, tin and copper, the very ingredients of bronze, were highly sought after. The tin and copper mines of Cornwall were of great international significance, particularly during the second millennium BC (Atkinson, 1985, 1987; Buckley, 1992). The initial sources of tin ore were alluvial deposits in streams and rivers draining catchments with a high representation of tin. These ores were concentrated by the process of tin streaming which caused huge amounts of sifted sediment to accumulate downstream, particularly at the top of the estuaries of the rivers (Buckley, 1992; Rainbow, 2018). Later, the outcropping of veins containing tin in sea cliffs such as at Geevor in the St Just area and at St Agnes offered a further accessible source of tin in Cornwall. Similarly copperrich veins could also be clearly seen in the cliffs at St Just, Illogan, St Agnes and Perranzabuloe. Mining for tin and copper in Cornwall became prevalent and was to last, albeit intermittently, for more than 2000 years (Rainbow, 2018). Over history, the amounts of tin and copper ores (and indeed other metal ores) extracted from Cornish mines were to depend on the sizes and richness of deposits, the mining technology (particularly drainage pump technology) available, and the international competitive demand (and therefore price) of the metals, itself changing with the discovery of overseas ore fields and of new uses for the metals in a developing industrial world (Rainbow, 2018).

Beyond tin and copper, lead, zinc and silver were also mined in south-west England from the Middle Ages forward. The silver mines on the Bere Alston peninsula north of Plymouth were of national significance in the Middle Ages, and the catchment of the River Gannel above Newquay was a rich source of lead, particularly in the 19th century (Rainbow, 2018). Demand for arsenic rose at the end of the 19th century for use in insecticides for the control of pests in the potato and cotton fields of the USA, renewing interest in the arsenic ore previously almost disregarded in the spoil heaps of Cornish copper mines (Rainbow, 2018). Iron was also mined as demand increased after the onset of the industrial revolution in the late 18 th century.

\section{Ecotoxicity}

There was an environmental price to be paid by Cornwall for the development of mining as a dominant local industry. All trace metals are ecotoxic above a threshold availability in any habitat, including estuaries. In Cornwall it is typically copper, and to a lesser extent its associate arsenic, that offer the greatest ecotoxicological threat (Rainbow, 2018). Lead and zinc are ecotoxicological drivers in aquatic habitats where sediments rich in these metals occur, as in the Gannel catchment, but the wider distributions of ores of copper and arsenic in the county led to the ecotoxicological predominance of these two trace metals.

But what of tin and iron in the aquatic ecosystems of Cornwall? As it happens neither is a major direct source of aquatic ecotoxicity. Tin is predominantly found as cassiterite (tin oxide), known in Cornwall and Devon as black tin. Tin in this form is very strongly bound and not easily released from the ore in dissolved form into fresh water or estuarine waters to impact directly on the local aquatic biota. The major detrimental environmental impact, for example of tin streaming, is by physical smothering of the flora and fauna by fine sediment. Iron released into solution from its common sulphide ore iron pyrite rapidly oxidizes in oxygenated waters to form iron oxides and hydroxides which are practically insoluble and precipitate from the water column as ochre. There is little toxic dissolved iron left in solution in most streams but ochre too has a physical blanketing effect to cause depletion of the flora and fauna of streams and rivers. Any remaining dissolved iron, more pronounced for example in acidic fresh waters, will be transported downstream to the estuary. Here the dissolved iron ions encounter the more alkaline $\mathrm{pH}$ caused by the admixture of seawater, again promoting precipitation of the dissolved iron as iron oxides and hydroxides to be incorporated into the now estuarine sediment (Bryan \& Gibbs, 1983). Furthermore, the formation of particulate iron oxides and hydroxides provides surfaces for the adsorption of certain other trace metals including copper and arsenic. These trace metals come out of solution to be deposited in the estuarine sediments in association with the particulate iron oxides and hydroxides (Bryan \& Gibbs, 1983; Langston, 1983; Bryan \& Langston, 1992).

In contrast to tin and iron, copper, arsenic, lead, zinc and silver do have the potential to offer a direct ecotoxicological challenge in dissolved form to freshwater and estuarine fauna and flora. The mined ores of each are typically sulphides. Chalcopyrite, a sulphide of copper and iron, is the dominant copper ore in Britain including Cornwall, where it is known as yellow copper ore (Dines, 1969). The economically important ore of arsenic in Cornwall and elsewhere in Britain is arsenopyrite, known historically as mispickel, an iron arsenic sulphide. Galena (lead sulphide) is the principal ore of lead, and is easily smelted to release lead. Sphalerite, the chief ore of zinc, is known as zincblende or blende, and popularly as black jack. Sphalerite consists predominantly of zinc sulphide, but almost always contains some iron. While not a pure ore of silver, argentiferous galena is usually the most important mined source of the metal. Argentiferous galena may contain 1-2\% of silver associated with the predominantly lead sulphide of galena. These trace metals are typically released into solution during the mining and subsequent processing of the sulphide ores, to remain in solution, often in concentrations so high as to be ecotoxicologically significant (Rainbow, 2018).

\section{History of selected Cornish catchments}

It is a remarkable feature of many Cornish estuaries just how much sediment has been deposited there, considering the actual size of the parent rivers. Consider the very large areas of salt marsh occupying the extensive sediment banks associated with, for example, the Gannel and West Looe Estuaries. How could such small rivers deposit so much sediment? The answer lies in the old mining practices of washing large amounts of waste ore material into rivers, filling their estuaries downstream with sediments with raised trace metal contents. These sediments remain today.

It is not possible here to consider all metal-contaminated Cornish estuaries. Inevitably it has proved necessary to select particular catchments, rivers and estuaries. 


\section{Carnon}

The River Carnon drains one of the most heavily mined river catchments in Britain (Rainbow, 2018). The catchment extends from the historical copper and tin mining districts of Chacewater, St Day, Carharrack, Gwennap and Baldhu to the east of Redruth, past Twelveheads and Bissoe, down to Devoran, at the head of the estuary Restronguet Creek (Figure 1). Restronguet Creek is part of the extensive Fal Estuary system on the south coast of Cornwall.

In the 18th century, Cornwall was the biggest producer of copper in the world by a wide margin (Buckley, 1992). Copper mines in the St Day area such as Chacewater (later known as Wheal Busy) produced large tonnages of copper ore, as did the nearby Poldice mine (Figure 1) (Rainbow, 2018). In the 18th and early 19th centuries, copper mining changed the face of Cornwall, particularly the Carnon valley, as St Day, Chacewater and other villages became centres of industry (Buckley, 1992). Mines expanded and coalesced into large joint enterprises. What was to become known as the Great County Adit was started in 1748 to drain the Poldice mine, ultimately into the River Carnon (Buckley, 1992). The adit expanded into the most ambitious drainage adit ever driven in Cornwall, with branches to many neighbouring mines in the Carnon valley and also in the adjacent Redruth and Camborne area. The Great County Adit continued expansion in the 19th century, and, by 1880 , it consisted of a network of drainage channels 40 miles long, serving more than 60 mines (Buckley, 1992). At its peak, the Great County Adit discharged more than 65 million litres per day into the River Carnon, and thence into Restronguet Creek. The Great County Adit was a key factor in the success of an area that was for many decades the richest mining district in the world.

Extraction of arsenic increased in importance in the Carnon valley during the 19th century as demand for arsenic-based insecticides grew, particularly in the USA. Arsenopyrite (mispickel) is mainly associated with chalcopyrite in the copper zone, but it is occasionally found with black tin at the top of the tin zone below the copper (Dines, 1969). Mispickel had long been considered as an undesirable contaminant of a copper or tin vein, with arsenic oxide (arsenic soot) being emitted from smelters or deposited as a grey powder in smelter chimneys. This arsenic soot could be collected and refined into white arsenic, consisting of almost pure arsenic oxide (Dines, 1969). There was an existing and already growing market for white arsenic in the 19th century for the manufacture of glass and fireworks, the tanning of leather and for pigments to colour cotton fabrics and wallpapers (Barton, 1971). In 1812, a former tin smelting house near Perranarworthal in the Carnon valley was adapted to produce commercial quantities of arsenic, and in the 1830s a second arsenic works was established at nearby Bissoe (Figure 1) (Barton, 1971).

Attention turned to the previously unwanted arsenic in the thousands of tonnes of discarded mispickel in the spoil heaps of the Carnon valley. The emission of arsenic from the chimneys of arsenic works was however creating severe ecotoxicological problems for livestock downwind, as in the cases of the works at Perranarworthal and at Great Wheal Busy (previously the Chacewater mine) (Barton, 1971). The installation at arsenic works of a cooling and washing flue to remove arsenic before the chimney stack ameliorated the situation for neighbouring farmland, the waste water being led away to a settling pond (Barton, 1971). A new risk, however, emerged if ever the arseniccontaminated settling pond waters were to enter local watercourses. As in the cases of copper and tin before, the heyday of arsenic production in the Carnon valley was not to last. Increasing foreign competition and local US production of arsenic for insecticides meant the end of profitable arsenic production in the Carnon valley within the first decades of the 20th century.
Tamar

The River Tamar, marking part of the border between Cornwall and Devon, rises near Bude on the north coast before it flows southwards across the peninsula to Plymouth Sound. The Tamar passes Launceston before it flows through the historic mining region of Gunnislake, just north of the head of its estuary. In the upper part of its estuary, the Tamar is joined by its tributary the River Tavy draining Dartmoor (Figure 2).

The Gunnislake mines were mined extensively for copper, arsenic and lead in the 19th century, producing internationally very significant amounts of copper and arsenic. The rich copper vein serving the Gunnislake mines was itself nearly $3 \mathrm{~km}$ long, up to $13 \mathrm{~m}$ wide, and at least $600 \mathrm{~m}$ deep (Dines, 1969). Of the Gunnislake copper mines, the famous Devon Great Consols, incorporating Wheal Maria (Figure 2), produced 742,400 tons of copper ore between 1845 and 1903 (Dines, 1969). The Gunnislake mines were drained by adits into the River Tamar, carrying their contaminant metal loads into the river, and thence into the estuary.

In the face of foreign competition in the second half of the 19th century, the rich copper mines of the Tamar valley fared better than most south-western copper mines, but even these cut back production (Atkinson, 1987; Burt et al., 1987). Arsenic temporarily came to the rescue of the Gunnislake copper mines (Barton, 1971). In 1868, Devon Great Consols, the greatest copper mine in Britain, started exploitation of the arsenic ores in its possession (Barton, 1971), and in the 1870s Devon Great Consols was joined by Okeltor, Gawton (Figure 2) and Friendship, to the effect that these few mines in the Callington and Tavistock district were now producing half of the world's output of arsenic (Dines, 1969). Devon Great Consols had weathered the recession best, but by 1901 it too had closed.

The industrial revolution had brought increasing demand for lead for piping, building materials, castings and lead-based paints. Correspondingly lead production was strong in the first half of the 19th century in south-west England (Burt et al., 1987). The Bere Alston peninsula on the eastern bank of the upper Tamar Estuary had a long history of lead and silver mining, and the Bere Alston lead and silver mines were particularly active in the first decade of the century. Nineteenth century steam-power driving pumps had enabled mines in the Tamar valley to go deeper and under the River Tamar to rich pockets of lead ore containing silver (Dorrington \& Pyatt, 1982). By 1809, the Bere Alston mines were among the leading lead and silver mines in Britain, with local smelting at nearby Weirquay on the Tamar Estuary (Figure 2). As in the case of earlier attempts to smelt copper in Cornwall, coal needed to be imported to Weirquay, and the opportunity was also taken to import ore to be smelted in the smelters there (Dorrington \& Pyatt, 1982). By 1845 there were 18 smelters operating at Weirquay, but by 1865 these had ceased functioning, leaving behind spoil heaps of both local and foreign origin (Dorrington \& Pyatt, 1982).

The River Tavy has its own smaller upper estuary along the eastern side of the Bere Alston peninsula (Figure 2). The Tavy drains a mining region of Dartmoor just north of Tavistock, receiving, for example, the waters of the Cholwell Brook draining the Wheal Betsy Mine near Mary Tavy, a historic source of tin, lead, zinc and silver (Beane et al., 2016). After passing through Tavistock, the Tavy drains the eastern end of the Gunnislake region and the eastern side of the Bere Alston peninsula. Like the Tamar, the Tavy Estuary receives a significant input of copper, arsenic, lead and iron.

\section{Gannel}

The Gannel Estuary on the southern outskirts of Newquay receives the River Gannel rising in the village of Indian Queens 


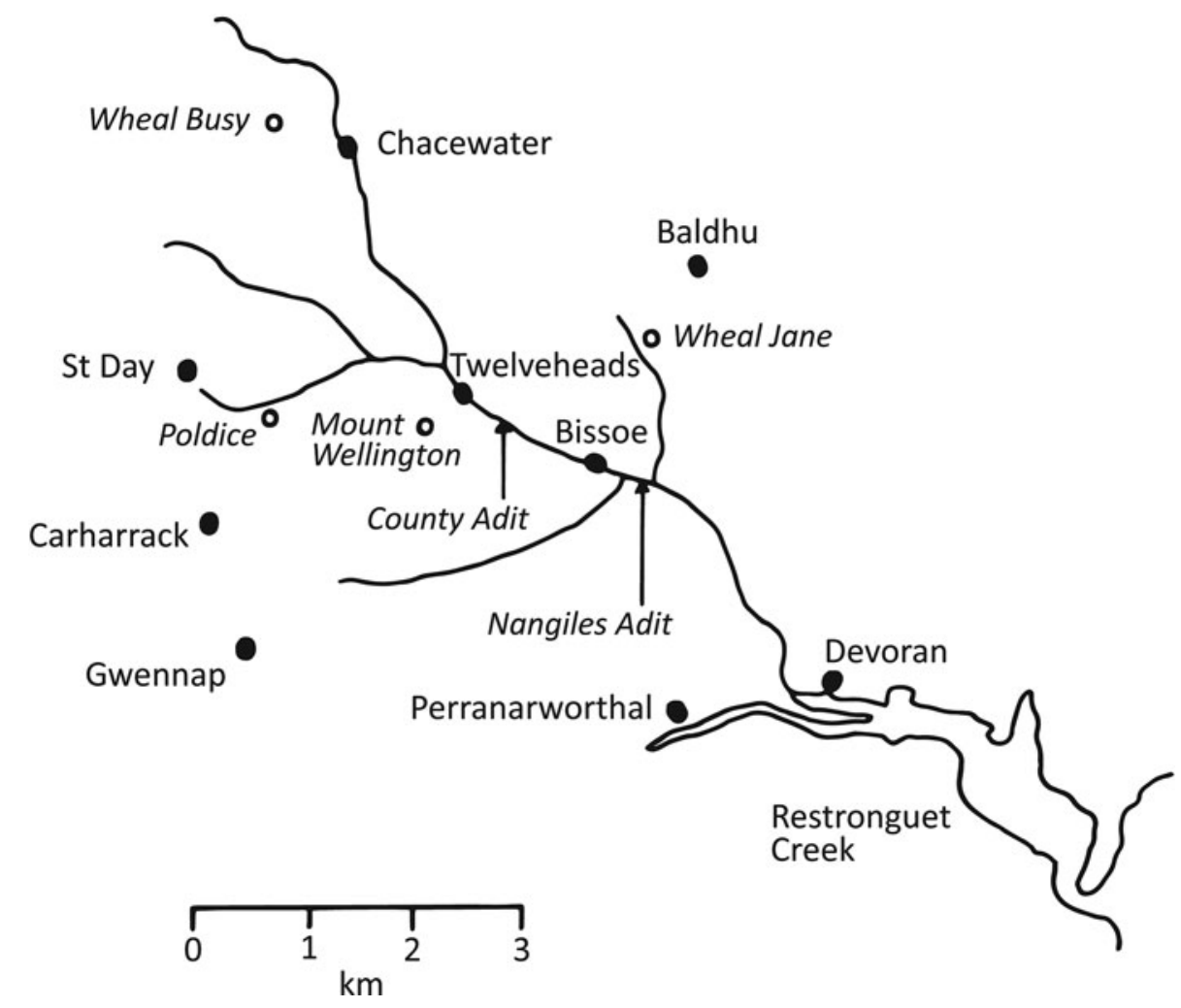

Fig. 1. River Carnon, Cornwall and associated mining areas (after Rainbow, 2018, with permission).
Today, the Hayle Estuary houses a nature reserve (a site of special scientific importance) managed by the Royal Society for the Protection of Birds, in reflection of the estuary's importance for migrant and wintering waterfowl and waders. The estuary, therefore, does not have the unrestricted access, even for scientific purposes, that is available at the other Cornish estuaries highlighted here. inant position of equivalent mines in the Pennines, Wales and Scotland (Burt et al., 1987). As in the Tamar valley, the mines of Newlyn Downs were particularly productive in the first half of the 19th century. Indeed East Wheal Rose at St Newlyn East was briefly the country's largest single lead mine in the mid-1840s (Burt et al., 1987). Lead production collapsed in the third quarter of the century to fizzle out by 1900 (Dines, 1969), as lead veins became exhausted and foreign competition increased. The production of silver from the argentiferous galena was able to offset the demise of lead mining in Cornwall to a limited extent, not least at East Wheal Rose (Dines, 1969; Burt et al., 1987).

\section{West Looe}

The Rivers West Looe and East Looe share a common estuary at Looe on the south Cornish coast (Figure 4). The West Looe River drains part of the old lead mining area of Herodsfoot, south-west of Liskeard, which produced both lead and silver in the 19th century (Dines, 1969). The East Looe River, on the other hand, does not pass through a mining region.

\section{Hayle}

The Hayle Estuary lies at the southern end of St Ives Bay on the north Cornwall coast, receiving the waters of the River Hayle (Figure 5). The Hayle catchment has had a long association with firstly tin and then copper mining. Tin was mined at Godolphin in the 16th century. In the first half of the 18th century, copper was raised at Wheal Fortune at St Hilary and the Godolphin mine was very active in copper production a century later up to the 1840 s.

\section{Trace metal status of selected Cornish estuaries}

Table 1 lists the concentrations of the trace metals of interest in the sediments of the estuaries selected above, and comparative data for an uncontaminated estuary in south-west England, the Avon Estuary in south Devon.

The raised trace metal concentrations in the contaminated estuaries are those to be expected from the historical discussion above. Thus the sediments of Restronguet Creek have exorbitantly high concentrations of arsenic, copper, zinc, iron and tin, with high concentrations also of lead, manganese and silver (Table 1), all delivered by the River Carnon. It is worth noting here that high concentrations of tin are only measured in the sediments of Restronguet Creek and the other Cornish estuaries when a very powerful fusion technique is used to release tin from the cassiterite particles in the sediment (Bryan \& Langston, 1992), for example ammonium iodide fusion (Bowman, 1968; Schweinsberg \& Heffernan, 1970). Tin is too tightly bound chemically in cassiterite to be released by more standard extraction agents such as concentrated nitric acid, a point to be considered below when considering the relationship between sediment concentrations and bioavailabilities.

While low in comparison to Restronguet Creek, the sediments of the Tamar and Tavy Estuaries still have raised concentrations of arsenic, copper, lead and zinc (Table 1). Gannel Estuary sediments have extremely high concentrations of lead and zinc, with raised silver also (Table 1). The West Looe Estuary sediments have high lead in particular (Table 1). The sediments of the Hayle Estuary have high arsenic and copper, but also lead and zinc 


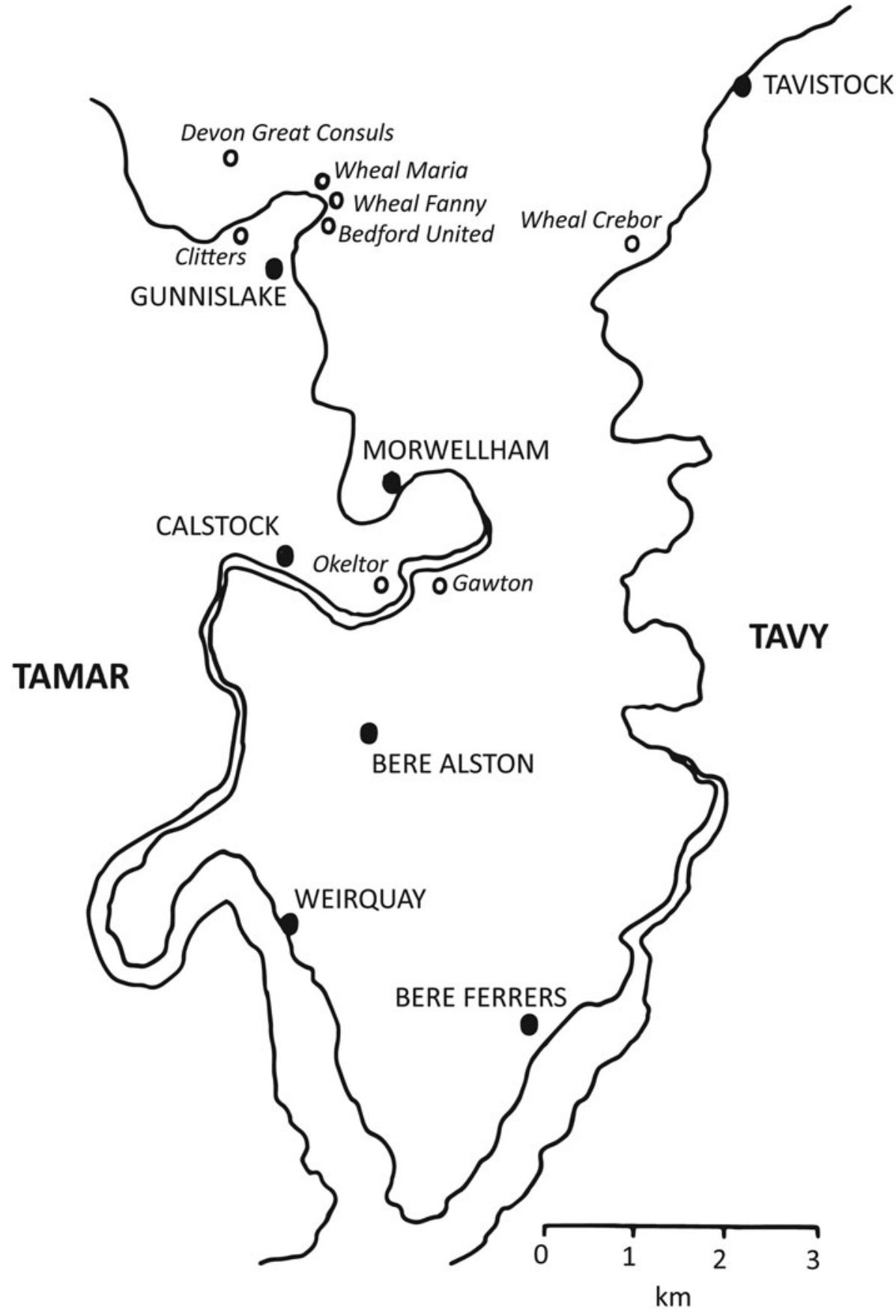

Fig. 2. Southern part of the River Tamar and adjacent River Tavy, Cornwall and Devon (after Rainbow, 2018, with permission).
(Table 1) indicating the additional presence of ores of these latter two trace metals in the catchment.

It is a feature of the sediment trace metal concentrations in all the contaminated estuaries (Table 1) that measurements decades apart do not show decreases over time (Rainbow et al., 2011a), indicating that the metals are strongly enough bound to the sediments not to be released into the overlying water and washed downstream. Thus sediment concentrations in these estuaries remain atypically high many decades after their deposition during mining activity upstream.

The strength of the chemical binding of toxic metals in the sediments has ecotoxicological consequences for the local estuarine fauna. We have seen above that tin is too strongly bound in cassiterite particles to be released to cause biological effects. For the other trace metals considered here, metals associated with sediment particles derived from their ores can be released from the sediment under certain circumstances and become available to local biota. Clearly the flow of water over the sediment each way over the tidal cycle has not been sufficient to wash out the sediment-associated metal over time.

Trace metals enter aquatic animals by two routes - from solution at permeable external surfaces, typically respiratory surfaces, and in the alimentary tract after ingestion and digestion (Rainbow, 2018). In the body of a sediment, the particles will be bathed by pore water. If a sediment is rich in organic matter, as is typical for estuarine muds, microbial respiration uses up the available oxygen to create reducing, even anoxic, conditions in the pore water. These conditions will promote the exchange of particular trace metals such as iron and manganese from the sediment particles into the pore water because of the higher solubilities of the reduced iron 2 and manganese 2 cations than their oxidized counterparts iron 3 and manganese 4 which precipitate from solution as hydroxides and oxides. Such raised dissolved concentrations in the pore water under hypoxic or anoxic conditions are not a characteristic feature for most trace metals, and even for iron and manganese they actually have relatively little 


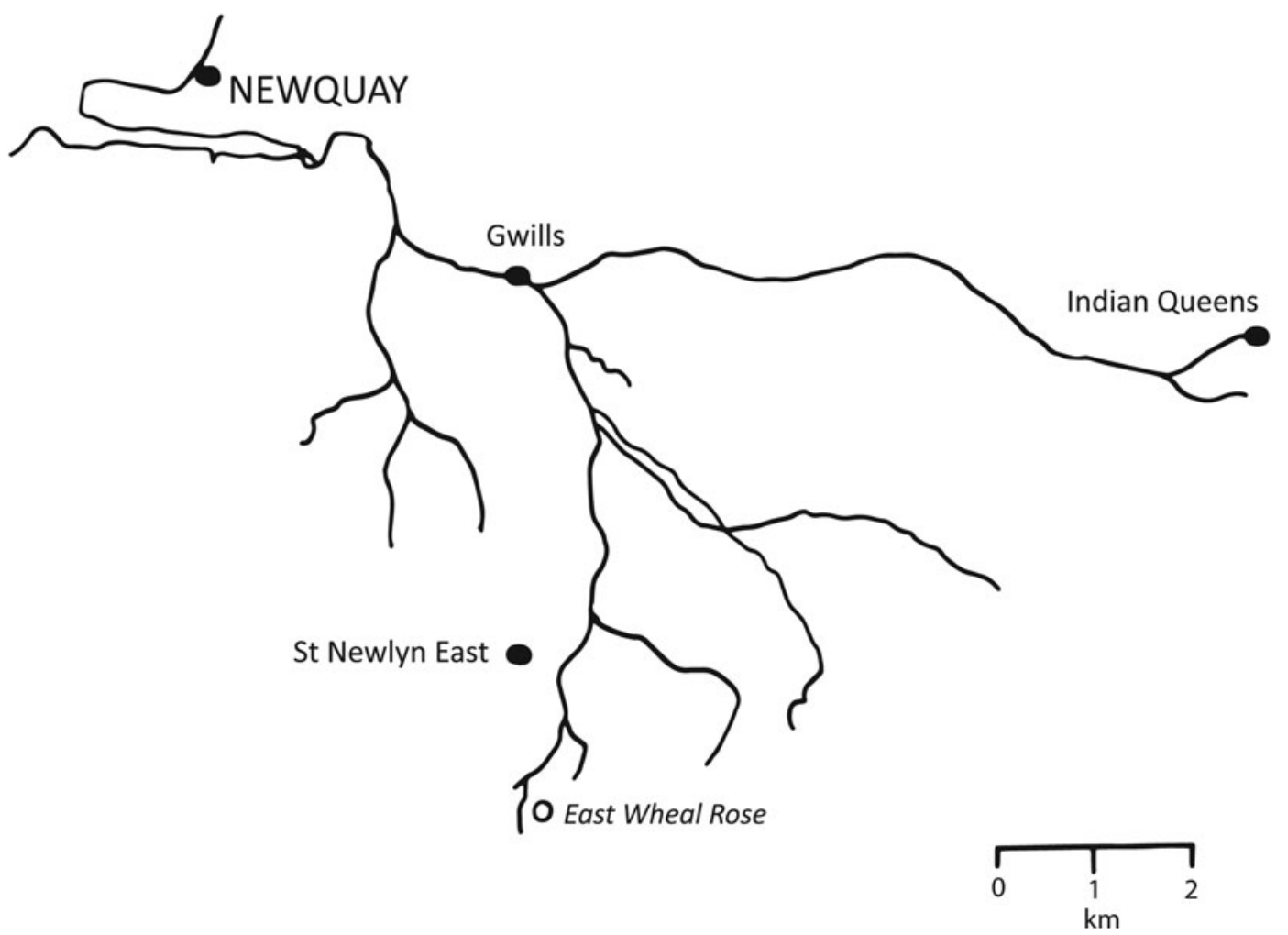

Fig. 3. River Gannel, Cornwall (after Rainbow, 2018, with permission).

effect on animals burrowing in the sediment. The reason lies in the fact that burrowing animals create temporary or permanent burrows through which they pump respiratory currents (which may also be feeding currents for suspension feeders) of oxygenated water from the overlying water column (Rainbow, 2018). Thus burrowing animals are not bathed in pore water and dissolved trace metal concentrations in sediment pore water are not the significant source of trace metal uptake for sediment infauna once believed (Rainbow, 2018).

More significant is the uptake of sediment-associated trace metals by animals that ingest the sediment, be it newly deposited sediment particles lying on the sediment surface as in the case of the bivalve Scrobicularia plana, the peppery furrow shell, or deeper sediments as by the estuarine ragworm Hediste diversicolor (Rainbow, 2018). These ingested sediments are subject to the digestive powers of the deposit feeder which release the sediment-associated trace metals for uptake by the animal. It follows that the conditions in the alimentary tract (presence of digestive enzymes, $\mathrm{pH}$, etc.) are strong enough to overcome the chemical binding of the metals in the sediment particles and release them into solution to be taken up across the epithelia of the alimentary tract. In short, these trace metals are trophically bioavailable to the feeding animal. Not necessarily all of a sediment-associated trace metal will be released, depending on the chemical constitution of the sediment particle and the strength of the digestive process encountered (Rainbow et al., 2011b).

Other physical factors also influence the availabilities of trace metals in sediments, such as the presence of organic ligands affecting copper and mercury bioavailabilities and iron oxyhydroxide coatings on particulate matter affecting the sediment bioavailabilities of arsenic and lead (Bryan \& Langston, 1992). Salinity too is a master variable affecting the bioavailabilities of sediment-associated trace metals (Bryan \& Langston, 1992).

Table 1 presents information on the sediment digestion technique used to solubilize the trace metals in the sediment for analysis. Digestion with concentrated nitric acid (typically at $100^{\circ} \mathrm{C}$ ) is strong enough for the resulting metal concentration often to be termed the total metal concentration of the sediment, although, as in the case of cassiterite, a smaller or larger portion of the constitutive metal in the sediment particle may not be dissolved. What is certain, though, is that all sediment metal that is potentially bioavailable to any organism (either after ingestion or after release into solution in pore water or water column) will be included as part, but probably not all, of this total concentration.

It is not possible to measure directly by chemical analysis the trace metal concentration in a sediment that can be identified as bioavailable, bioavailability varying with the organism under consideration (Rainbow, 2018). Nevertheless various relative weak extraction procedures have been used in attempts to model the fraction of the trace metal in a sediment that might be considered bioavailable. Hence Table 1 contains sediment concentrations of trace metals in the contaminated estuaries after extraction with weak hydrochloric acid as a better representation of the metal that might offer an ecotoxicological threat to the local estuarine biota. It is apparent that the 2003 data in Table 1 for Restronguet Creek, the Tavy, the Gannel and West Looe show that the weakly exchangeable trace metals in their estuarine sediments are usually in excess of half of total trace metal concentrations, and as high as $86 \%$ in the case of lead in the West Looe Estuary (Rainbow et al., 2011a).

It can be concluded then that particular metal-contaminated estuaries in Cornwall contain sediments with atypically very high concentrations of trace metals as a legacy of mining in their river catchments. These concentrations have persisted over decades and are still high today. What is more, it appears that large proportions of the trace metal contents of these sediments are not so strongly bound as to be unavailable to local estuarine biota. To explore this potential in more detail we need to turn to organisms themselves, not least to biomonitors. Trace metal biomonitors are organisms which accumulate trace metals in their tissues, the accumulated concentrations of which provide relative measures of the total amounts of the trace metal taken 


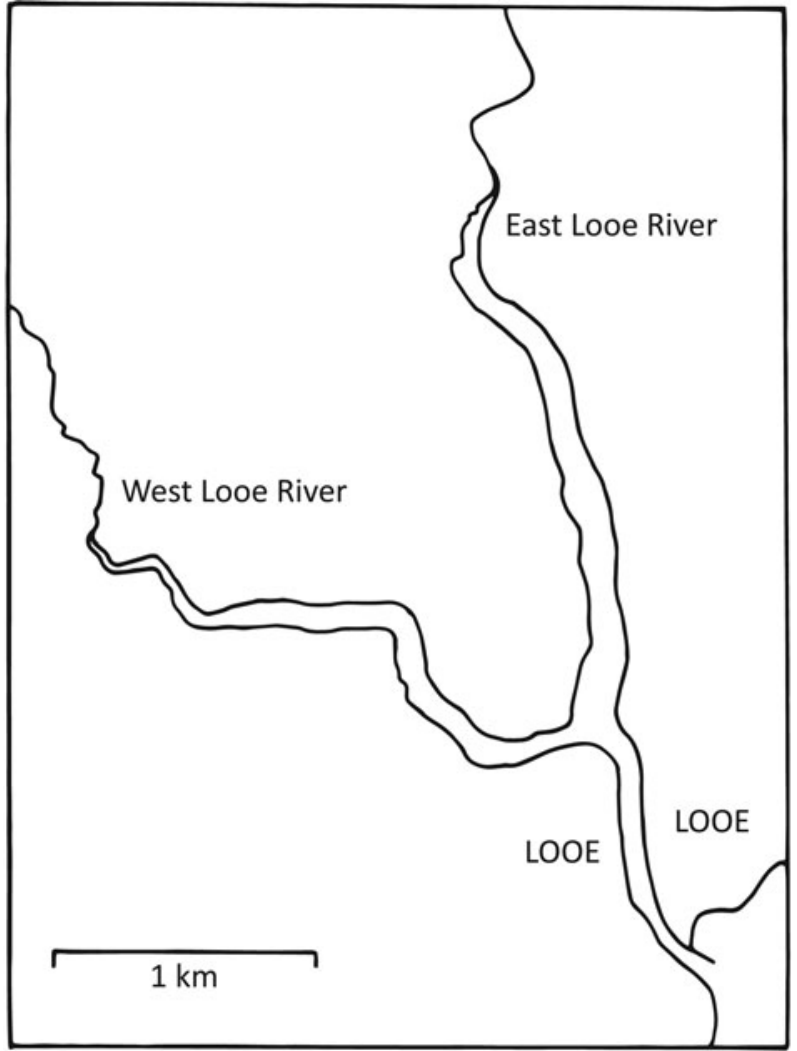

Fig. 4. Looe Estuary, Cornwall (after Rainbow, 2018, with permission).

up by all routes by that organism, integrated over a preceding time period (Rainbow, 2018).

\section{Trace metal biomonitors in estuaries}

Biomonitors provide different information on the relative strengths of trace metal sources in different estuaries according to the presence and predominance of the different routes of trace metal uptake that they show (Rainbow, 2018).

A seaweed such as bladder wrack Fucus vesiculosus will take up and accumulate trace metals only from solution so long as it is not in contact with local sediments (Bryan et al., 1985). It is therefore a good biomonitor of dissolved trace metal bioavailabilities. A classic biomonitor of trace metal bioavailabilities in solution and in suspended detritus and phytoplankton in European coastal waters is the mussel Mytilus edulis. However the mussel is rare in mining-affected estuaries in Cornwall (Rainbow, 2018). The deposit-feeding bivalve Scrobicularia plana takes up metals from solution in the water column and from particles deposited on the top of the sediment, thereby providing information on the bioavailabilities of trace metals in these two sources (Rainbow, 2018). Another surface deposit-feeding bivalve Macoma balthica, the Baltic tellin, can play a similar biomonitoring role lower down in mid-estuary, but, like M. edulis, it is rare in mining-affected estuaries in Cornwall (Bryan et al., 1980; Rainbow, 2018). The estuarine ragworm Hediste diversicolor has a variety of feeding methods including sediment ingestion and has been shown to be a good biomonitor of sediment trace metal bioavailabilities (Bryan \& Langston, 1992; Rainbow, 2018).

\section{Fucus vesiculosus}

Table 2 presents data on trace metal concentrations in F. vesiculosus from south-west British estuaries. These concentrations are typically measured in frond tissue near the tip and provide information on dissolved trace metal bioavailabilities integrated over the previous few months (Bryan et al., 1985; Rainbow, 2018). Some of the accumulated concentrations measured in the 21 st century are still somewhat raised above typical values, but have typically fallen considerably from very, very high concentrations measured in the 1970s (Table 2). Thus in Restronguet Creek there were extremely high bladder wrack concentrations of especially copper and zinc, but also arsenic, iron and manganese, in the 1970s and 1980s when there was still some mining being carried out in the Carnon Valley. Copper and zinc concentrations in bladder wrack were much lower in the first decade of this century after the cessation of mining (Table 2), indicating a decline in their dissolved bioavailabilities in Restronguet Creek (Rainbow et al., 2011a).

\section{Scrobicularia plana}

Concentrations of trace metals accumulated in the soft tissues of Scrobicularia plana in Cornish estuaries are listed in Table 3. Scrobicularia plana accumulates trace metals both from solution and from ingested sediments (Langston, 1984; Amiard et al., 1985; Kalman et al., 2014). The bioaccumulated concentrations in the bivalve reflect local sediment bioavailabilities of many trace metals (Langston, 1980; Luoma \& Bryan, 1982; Kalman et al., 2014), with the exception of copper (Bryan \& Langston, 1992). In fact $S$. plana attains a greater proportion of its accumulated content of several trace metals from solution than from ingested sediment, for example $66-99 \%$ and $52-98 \%$ of silver and zinc respectively under different field conditions (Kalman et al., 2014). Kalman et al. (2014) estimated that S. plana obtained between 50 and $97 \%$ of accumulated arsenic from solution while Langston (1984) concluded that the sediment is the major source of arsenic to this bivalve. Nevertheless $S$. plana is a biomonitor of trace metal bioavailabilities in both solution and ingested sediment.

As Table 3 shows, Restronguet Creek has ongoing very high total bioavailabilities to $S$. plana of arsenic, copper and zinc, and a slightly raised bioavailability of lead. Data for the Tamar Estuary in the 1970s identify a very high bioavailability of lead to S. plana (Table 3), the highest bioaccumulated concentrations occurring at the point of entry of effluent from the old South Tamar Mine, near Bere Alston (Bryan \& Uysal, 1978). The South Tamar Mine was abandoned in 1865 after flooding by water from the estuary breaking into the mine workings (Dines, 1969). The Gannel Estuary had, and still has, high bioavailabilities of lead and zinc to S. plana (Table 3). High bioavailabilities of lead (and also copper) to the bivalve in the West Looe Estuary have been maintained since the 1970s (Table 3). The data for the Hayle Estuary confirm high copper and arsenic bioavailabilities to this bivalve in the 1970s (Table 3).

There were significant decreases between 2003 and 2006 in the accumulated concentrations of some trace metals in S. plana in some mining-affected estuaries (Table 3), indicating falls in their bioavailabilities to the bivalve (Rainbow et al., 2011a). Thus, bioavailabilities of silver fell in Restronguet Creek and the Tavy, of lead in Restronguet Creek and the Gannel, and of zinc in Restronguet Creek (Table 3) (Rainbow et al., 2011a). These decreases presumably reflect falls in dissolved bioavailabilities, given the importance of this source of metals to $S$. plana (Rainbow, 2018).

\section{Hediste diversicolor}

Although the estuarine ragworm Hediste diversicolor can feed in a variety of methods, it is valid from the viewpoint of trace metal accumulation to consider it primarily as an ingestor of sediments (Rainbow, 2018).

Field evidence has shown up significant positive relationships between its bioaccumulated trace metal concentrations and those 


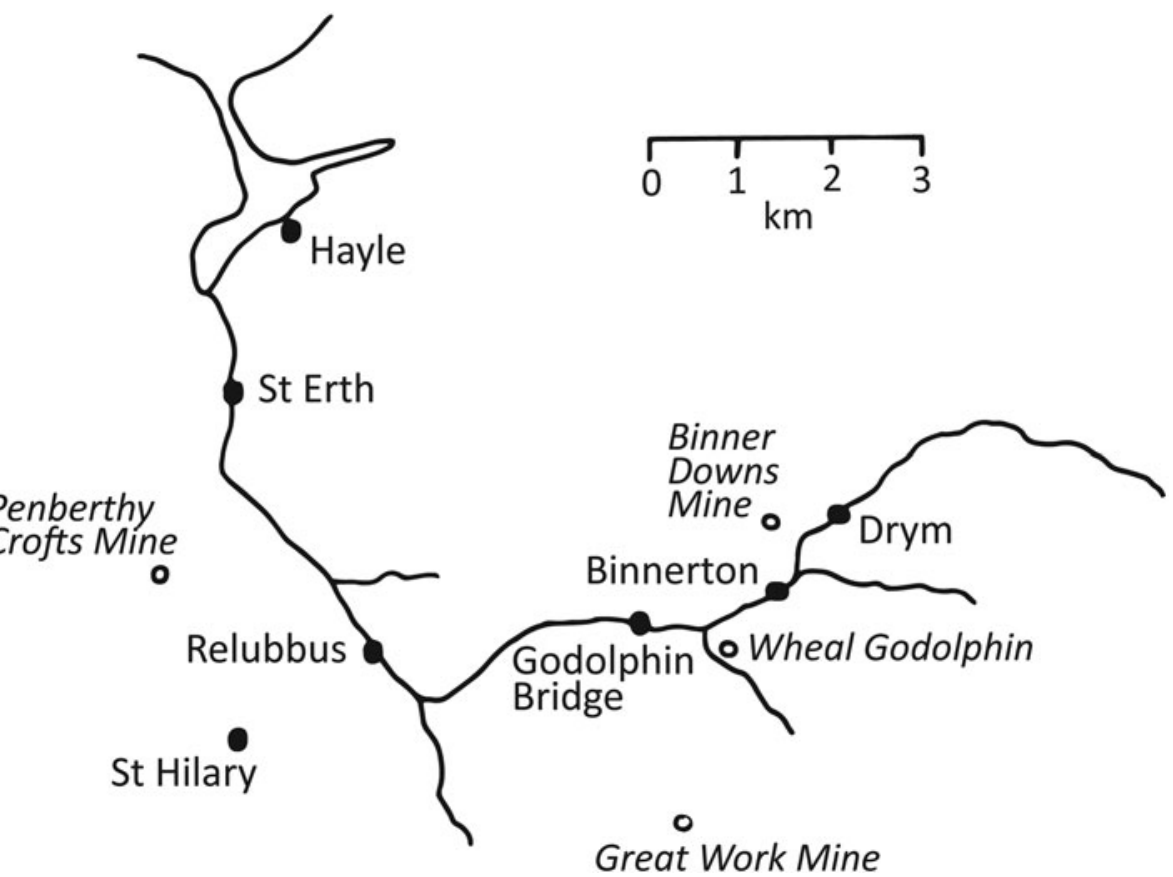

Fig. 5. River

Great Work Mine

in sediments (Bryan et al., 1980, 1985; Bryan \& Langston, 1992). It has also been demonstrated that arsenic, copper and lead are mostly bioaccumulated by $H$. diversicolor from ingested sediment (Bryan, 1984). In addition, biodynamic modelling has shown that between 52 and $96 \%$ of arsenic, more than $99 \%$ of cadmium and more than $98 \%$ of zinc accumulated by this ragworm is derived from sediment ingestion (Rainbow et al., 2009b, 2011c). The ragworm is, therefore, a biomonitor principally of bioavailable metals in the sediment. The trace metal silver is a partial exception, because between 46 and $80 \%$ of the silver accumulated by $H$. diversicolor is derived from dissolved silver as opposed to sediment-associated silver (Rainbow et al., 2009b).

Table 4 confirms that the bioavailabilities of sediment-associated trace metals to Hediste diversicolor, as reflected in their bioaccumulated concentrations, are typically related to the total sediment concentrations listed in Table 1.

In Restronguet Creek, sediment bioavailabilities to $H$. diversicolor have been, and still are, particularly high for copper, zinc and arsenic, and also raised to a lesser degree for silver, and possibly lead (Table 4). Furthermore there is no consistent evidence for a general decrease in these sediment bioavailabilities to the ragworm over decades (Table 4) (Rainbow et al., 2011a). The Tamar and Tavy Estuaries have somewhat raised sediment bioavailabilities of copper, arsenic and lead to the ragworm (Table 4). The sediment bioavailability of lead to H. diversicolor remains high in the Gannel Estuary (Table 4). The high concentrations of lead in the sediments of the West Looe estuary (Table 1), are reflected in high local sediment bioavailabilities of lead to $H$. diversicolor (Table 4). Sediment bioavailabilities of copper, arsenic and probably zinc to $H$. diversicolor were high in the Hayle Estuary in the 1970s and 1980s (Table 4). As in the case of Restronguet Creek, there is no consistent evidence for any general decreases in the sediment bioavailabilities of trace metals to $H$. diversicolor over decades in the mining-affected estuaries of the Tavy, the Gannel and West Looe (Table 4) (Rainbow et al., 2011a).

\section{Trace metal bioavailabilities in Cornish estuaries today}

It is clear then that the bioavailabilities of particular trace metals (one or more of arsenic, copper, lead and zinc) in the sediments of particular Cornish estuaries remain exorbitantly high today, according to the mining history of the river catchment that they serve. Dissolved bioavailabilities on the other hand have fallen over the decades since the cessation of mining. These dissolved trace metal bioavailabilities may still occasionally be somewhat raised above those of estuaries considered uncontaminated, but cannot be considered to be elevated to anywhere near the same degree as the bioavailabilities of the sediment-associated trace metals.

Thus the biologically available fractions of arsenic, copper, lead and zinc in the sediments have been sufficiently tightly bound so that they have not been leached significantly into the water column over time. On the other hand, they have not been so tightly bound chemically that they cannot be released for assimilation by the digestive powers of invertebrates ingesting the sediment. Tin remains an exception, being so tightly bound as to resist both leaching and assimilation.

\section{Trace metal ecotoxicity in Cornish estuaries}

We now come to the 'so what?' question. Are these high sediment bioavailabilities of trace metals of any ecotoxicological significance in the contaminated estuaries of Cornwall? How do we recognize the presence of such effects?

Ecotoxic effects of contaminants including trace metals on organisms can be recognized at all levels of biological organization from molecular through biochemical, cytological, histological, physiological, morphological, individual and population levels to finally a response at the community level, changing the structure of the community otherwise expected to be present in an equivalent uncontaminated estuary (Rainbow, 2018). Ascent through these levels of biological organization is associated with an increase in ecotoxic effect. A few toxic metal ions binding onto the wrong biological molecule lie at one end of the toxic exposure spectrum, a depleted biological community at the other, with major consequences for the ecological functioning of that community.

Ecotoxic effects along much of this increasing gradient of toxic exposure can be recognized by the use of biomarkers. A biomarker is a biological response (e.g. a biochemical, cellular, physiological or behavioural variation) that can be measured at the lower levels of biological organization in tissues or body fluids, 
Table 1. Mean or typical concentrations ( $\mu \mathrm{g} \mathrm{g}^{-1}$ dry weight) of trace metals in the oxic surface sediments $(<100 \mu \mathrm{m})$ of south-west British estuaries (a) affected by mining contamination or (b) considered uncontaminated

\begin{tabular}{|c|c|c|c|c|c|c|c|c|c|}
\hline & $\mathrm{Ag}$ & As & $\mathrm{Cd}$ & $\mathrm{Cu}$ & $\mathrm{Fe}$ & $\mathrm{Mn}$ & $\mathrm{Pb}$ & $\mathrm{Sn}$ & $\mathrm{Zn}$ \\
\hline Digest & & & & & & & & & \\
\hline
\end{tabular}

(a) Mining

\begin{tabular}{|c|c|c|c|c|c|c|c|c|c|c|}
\hline \multicolumn{11}{|c|}{ Restronguet Creek } \\
\hline $1974-80^{1}$ & $\mathrm{HNO}_{3}$ & 4.1 & 2520 & 1.3 & 2540 & 63,000 & 559 & 396 & $1350^{a}$ & 3520 \\
\hline Pre-1992 ${ }^{2}$ & $\mathrm{HNO}_{3}$ & 3.8 & 1740 & 1.5 & 2400 & 49,100 & 485 & 341 & 56 & 2820 \\
\hline $2003^{3}$ & $\mathrm{HNO}_{3}$ & 4.3 & & & 4210 & & & 336 & & 3620 \\
\hline $2003^{3}$ & $0.6 \mathrm{M} \mathrm{HCl}$ & 1.2 & & & 2890 & & & 168 & & 2200 \\
\hline \multicolumn{11}{|l|}{ Tamar } \\
\hline $1974-80^{1}$ & $\mathrm{HNO}_{3}$ & 0.9 & 85 & 1.5 & 305 & 28,100 & 758 & 156 & $106^{\mathrm{a}}$ & 392 \\
\hline Pre-1992 ${ }^{2}$ & $\mathrm{HNO}_{3}$ & 1.2 & 93 & 1.0 & 330 & 35,100 & 590 & 235 & 8 & 452 \\
\hline \multicolumn{11}{|l|}{ Tavy } \\
\hline $1974-80^{1}$ & $\mathrm{HNO}_{3}$ & 0.8 & 131 & 0.6 & 290 & 37,500 & 660 & 176 & $151^{\mathrm{a}}$ & 339 \\
\hline $2003^{3}$ & $\mathrm{HNO}_{3}$ & 1.2 & & & 261 & & & 176 & & 351 \\
\hline $2003^{3}$ & $0.6 \mathrm{M} \mathrm{HCl}$ & 0.5 & & & 187 & & & 129 & & 218 \\
\hline \multicolumn{11}{|l|}{ Gannel } \\
\hline $1974-80^{1}$ & $\mathrm{HNO}_{3}$ & 2.9 & 233 & 3.0 & 217 & 26,800 & 1160 & 2175 & $550^{\mathrm{a}}$ & 1215 \\
\hline Pre- $1992^{2}$ & $\mathrm{HNO}_{3}$ & 4.1 & 174 & 1.4 & 150 & 25,400 & 649 & 2750 & 9 & 940 \\
\hline $2003^{3}$ & $\mathrm{HNO}_{3}$ & 2.0 & & & 141 & & & 1230 & & 870 \\
\hline $2003^{3}$ & $0.6 \mathrm{M} \mathrm{HCl}$ & 0.8 & & & 98 & & & 781 & & 701 \\
\hline \multicolumn{11}{|l|}{ West Looe } \\
\hline $1974-80^{1}$ & $\mathrm{HNO}_{3}$ & 1.3 & 12 & 0.3 & 57 & 20,100 & 477 & 256 & $54^{\mathrm{a}}$ & 145 \\
\hline $2003^{3}$ & $\mathrm{HNO}_{3}$ & 2.7 & & & 71 & & & 485 & & 157 \\
\hline $2003^{3}$ & $0.6 \mathrm{M} \mathrm{HCl}$ & 1.2 & & & 42 & & & 416 & & 69 \\
\hline \multicolumn{11}{|l|}{ Hayle } \\
\hline $1974-80^{1}$ & $\mathrm{HNO}_{3}$ & 1.3 & 550 & 1.0 & 782 & 51,200 & 742 & 218 & $1750^{a}$ & 942 \\
\hline$\sim 2005^{4}$ & XRF & & $57-2290$ & & $88-4140$ & & & $30-522$ & $632-5460$ & $264-1780$ \\
\hline
\end{tabular}

(b) Uncontaminated

\begin{tabular}{clllllllll}
\hline Avon (Devon) & \multicolumn{10}{c}{} & & & & & & \\
\hline $1974-80^{1}$ & $\mathrm{HNO}_{3}$ & 0.1 & 13 & 0.3 & 19 & 19,400 & 417 & 39 \\
\hline Pre-1992 & $\mathrm{HNO}_{3}$ & 0.1 & 13 & 0.1 & 18 & 18,400 & 326 & 68 \\
\hline
\end{tabular}

${ }^{\mathrm{a}}$ Fusion technique to include cassiterite not digested by $\mathrm{HNO}_{3}$; XRF, X-ray fluorescence.

Sources: Bryan et al. $(1980)^{1}$, Bryan \& Langston $(1992)^{2}$, Rainbow et al. $(2011 a)^{3}$, Rollinson et al. $(2007)^{4}$

or at the level of the whole organism (Rainbow, 2018). The advantages of measuring biomarkers are that they typically involve less resource commitment than would be needed for a measure of community structure, and that they denote a degree of ecotoxicity less than that which would be drastic enough to cause community change (Rainbow, 2018). Different biomarkers would contribute different lines of evidence in a Weight of Evidence approach to investigate the potential ecotoxicology of trace metals in an estuarine habitat (Chapman, 2007; Benedetti et al., 2011).

A variation on this theme offering another line of evidence would be the presence of a metal-tolerant population in a particular habitat, an estuary in this case. Trace metal tolerance is a characteristic of a particular metal-exposed population of a species that is able to show higher survival, growth, etc. than other populations of the same species, when exposed to a very high bioavailability of the toxic metal. Metal tolerance may be inheritable after selection over several generations, or may be derived by physiological acclimation and be restricted to the one exposed generation. The presence of a metal-tolerant population of an organism in a particular habitat is evidence that local bioavailabilities of that toxic metal are of ecotoxicological significance, clearly to that species, but potentially also to other members of the local biota (Luoma, 1977).

The concept that the development of trace metal tolerance in a population of a single species shows that the local exposure to that trace metal is of ecotoxicological significance can be extended to the whole community. Thus the selection pressure associated with an ecotoxicologically significant trace metal bioavailability will lead to an increased average tolerance to that metal amongst all species in the local community (Blanck et al., 1988). Strictly it should be recognized that this increased average tolerance might well be based on (or include) changes in the relative abundance of metal-resistant species in addition to any selection of metal tolerant populations of particular species. Pollution Induced Community Tolerance (PICT) is a potential ecotoxicological tool to assess the effects of a toxicant on communities (Blanck 
Table 2. Mean, range or range of mean concentrations ( $\mu \mathrm{g} \mathrm{g}^{-1}$ dry weight) of trace metals in bladder wrack Fucus vesiculosus from south-west British estuaries (a) affected by mining contamination or (b) considered uncontaminated

\begin{tabular}{|c|c|c|c|c|c|c|c|c|}
\hline & $\mathrm{Ag}$ & As & $\mathrm{Cd}$ & $\mathrm{Cu}$ & $\mathrm{Fe}$ & $\mathrm{Mn}$ & $\mathrm{Pb}$ & $\mathrm{Zn}$ \\
\hline \multicolumn{9}{|l|}{ (a) Mining } \\
\hline \multicolumn{9}{|c|}{ Restronguet Creek } \\
\hline $1975-77^{1}$ & & $38-184$ & $1.1-1.3$ & $86-91$ & & & & $710-738$ \\
\hline $1981^{2}$ & $0.6-2.2$ & & $0.8-1.4$ & $717-1450$ & $2030-13,500$ & $61-533$ & $16-68$ & $2440-4200$ \\
\hline $1981^{3}$ & & $69-382$ & & & & & & \\
\hline $2006^{4}$ & 0.4 & 128 & & 166 & & & 10 & 449 \\
\hline \multicolumn{9}{|l|}{ Tamar } \\
\hline $1981^{3}$ & & $38-59$ & & & & & & \\
\hline $1982^{2}$ & 0.2 & & 0.8 & 27 & 631 & 78 & 11 & 113 \\
\hline \multicolumn{9}{|l|}{ Tavy } \\
\hline $2006^{3,4}$ & 0.5 & 86 & & 88 & & & 45 & 382 \\
\hline \multicolumn{9}{|l|}{ Gannel } \\
\hline $2006^{4}$ & 0.3 & 31 & & 15 & & & 33 & 206 \\
\hline \multicolumn{9}{|l|}{ West Looe } \\
\hline $2006^{4}$ & 0.7 & 22 & & 16 & & & 34 & 135 \\
\hline \multicolumn{9}{|l|}{ Looe } \\
\hline $1975-1976^{5}$ & 0.8 & & 1.3 & 17 & 1450 & 363 & 38 & 198 \\
\hline Mouth $1976^{2}$ & 0.4 & & 1.4 & 8 & 121 & 94 & 3 & 104 \\
\hline $2006^{4}$ & 0.5 & 29 & & 21 & & & 31 & 125 \\
\hline \multicolumn{9}{|l|}{ Hayle } \\
\hline $1977^{2}$ & 0.8 & & 2.3 & 436 & 4810 & 149 & 32 & 1860 \\
\hline \multicolumn{9}{|c|}{ (b) Uncontaminated } \\
\hline \multicolumn{9}{|l|}{ Torridge (Devon) } \\
\hline $1980^{2}$ & 0.3 & & 1.2 & 10 & 746 & 193 & 5 & 99 \\
\hline $1981^{3}$ & & $21-30$ & & & & & & \\
\hline Typical $^{6}$ & $0.1-1.0$ & $4-30$ & $0.2-2.5$ & $7-75$ & $35-250$ & $35-100$ & $1-20$ & $20-100$ \\
\hline $\mathrm{High}^{6}$ & $2-10$ & $50-500$ & $4-100$ & $200-1500$ & $500-14,000$ & $140-700$ & $20-610$ & $500-11,000$ \\
\hline
\end{tabular}

Sources: Klumpp \& Peterson $(1979)^{1}$, Bryan \& Gibbs $(1983)^{2}$, Langston $(1984)^{3}$, Rainbow et al. $(2011 a)^{4}$, Bryan \& Hummerstone $(1977)^{5}$, Rainbow $(2018)^{6}$.

et al., 1988). PICT is tested by comparing responses of communities collected from metal-contaminated and reference sites to metal exposure under controlled conditions. Any increased community tolerance that results from the elimination of more sensitive species is considered to be strong evidence that community restructuring has been caused by the toxic metal (Clements \& Rohr, 2009). PICT has been tested in several different communities including meiofaunal communities of nematode worms and harpacticoid copepods living in estuarine sediments with high trace metal concentrations (Somerfield et al., 1994; Millward \& Grant, 1995; Grant \& Millward, 1997).

Are ecotoxicological effects apparent in our example metalcontaminated Cornish estuaries?

Restronguet Creek still contains exorbitantly high concentrations of many trace metals, notably arsenic, copper, manganese, iron and zinc, in its sediments. The atypically very high concentrations of trace metals in the physical components of this estuary have been translated into very high bioavailabilities of these trace metals to a wide range of local organisms (Bryan \& Gibbs, 1983). Three of these trace metals, arsenic, copper and zinc, are the most likely candidates to be of ecotoxicological concern.

It was shown in the early 1980s that the growth rates of Fucus vesiculosus from Restronguet Creek were unaffected by dissolved concentrations of copper that reduced the growth rate of a bladder wrack population from the Tamar Estuary (Bryan \& Gibbs, 1983). High dissolved concentrations of zinc negatively affected the growth rates of both populations similarly. The Restronguet Creek population of bladder wrack was, therefore, tolerant to high dissolved bioavailabilities of copper, but not zinc, with no such tolerance in the Tamar Estuary population (Bryan \& Gibbs, 1983). Dissolved copper bioavailabilities in Restronguet Creek were therefore of ecotoxicological significance in the 1980s, although they have fallen since (Table 2) (Rainbow et al., 2011a).

Similarly the population of the peppery furrow shell Scrobicularia plana in Restronguet Creek in the 1970s was also tolerant to copper, but not zinc (Bryan \& Gibbs, 1983), again indicating that the local bioavailability of copper was of ecotoxicological significance. Scrobicularia plana takes up and accumulates trace metals from (predominantly) water and from ingested sediment. In the 1970s it is likely that both high dissolved and trophic bioavailabilities of copper were contributing to the development of the coppertolerant population of this bivalve.

The ragworm Hediste diversicolor also takes up and accumulates trace metals from dissolved and ingested sediment sources, but generally more of its total trace metal uptake is from the sediment than in S. plana. Also in the 1970s, the population of 
Table 3. Mean, weight-standardized estimate ( $0.2 \mathrm{~g}$ soft tissues), range of concentrations, or range of mean concentrations ( $\mu \mathrm{g} \mathrm{g}^{-1} \mathrm{dry}$ weight) of trace metals in soft tissues of the bivalve Scrobicularia plana (after depuration of gut contents) from south-west British estuaries (a) affected by mining contamination or (b) considered uncontaminated

\begin{tabular}{|c|c|c|c|c|c|c|c|c|c|}
\hline & $\mathrm{Ag}$ & As & $\mathrm{Cd}$ & $\mathrm{Cu}$ & $\mathrm{Fe}$ & $\mathrm{Mn}$ & $\mathrm{Pb}$ & Sn & $\mathrm{Zn}$ \\
\hline \multicolumn{10}{|l|}{ (a) Mining } \\
\hline \multicolumn{10}{|c|}{ Restronguet Creek } \\
\hline $1978-79^{1,2,3}$ & $0.2-0.3$ & $160-191$ & $2.3-4.5$ & $89-156$ & $2700-2860$ & $17-19$ & $50-72$ & $2.3-2.7$ & $2580-3160$ \\
\hline $0.2{\mathrm{~g} 2003^{4}}$ & 1.1 & & & 163 & & & 72 & & 1410 \\
\hline $0.2 \mathrm{~g} 2006^{4}$ & 0.21 & 146 & & 113 & & & 27 & & 999 \\
\hline $2013^{5}$ & 0.5 & 188 & & 232 & 4670 & 44 & 50 & & 2450 \\
\hline \multicolumn{10}{|l|}{ Tamar } \\
\hline $1974^{2,6}$ & $0.03-0.4$ & $29-47$ & $0.5-9.8$ & $13-52$ & $441-7280$ & $18-97$ & $26-296$ & $0.8-1.0$ & $1450-3990$ \\
\hline \multicolumn{10}{|l|}{ Tavy } \\
\hline $1974^{2}$ & 0.4 & 40 & 7.5 & 103 & 1100 & 32 & 81 & 0.8 & 2800 \\
\hline $0.2 \mathrm{~g} 2003^{4}$ & 1.2 & & & 69 & & & 40 & & 561 \\
\hline $0.2 \mathrm{~g} 2006^{4}$ & 0.4 & 30 & & 80 & & & 23 & & 520 \\
\hline $2013^{5}$ & 0.5 & 39 & & 113 & 4600 & 114 & 71 & & 2370 \\
\hline \multicolumn{10}{|l|}{ Gannel } \\
\hline $1974-75^{7}$ & $0.2-1.2$ & & $1.4-15$ & $25-86$ & $1120-1240$ & $57-87$ & $234-828$ & & $1470-2940$ \\
\hline $1977-79^{1,2,3}$ & $0.7-2.0$ & 98 & $1.9-14$ & $61-332$ & $1060-2730$ & $59-333$ & $309-1020$ & 0.9 & $2270-4920$ \\
\hline $0.2 \mathrm{~g} 2003^{4}$ & 0.8 & & & 113 & & & 593 & & 2190 \\
\hline $0.2 \mathrm{~g} 2006^{4}$ & & 75 & & 39 & & & 256 & & 1190 \\
\hline $2013^{5}$ & 0.4 & 50 & & 50 & 5100 & 300 & 263 & & 1510 \\
\hline \multicolumn{10}{|l|}{ West Looe } \\
\hline $1977^{2}$ & $6.8-10$ & $28-53$ & $1.3-2.1$ & $315-356$ & $580-1310$ & $49-70$ & $225-489$ & $1.2-1.6$ & $1280-2430$ \\
\hline $0.2 \mathrm{~g} 2003^{4}$ & 2.5 & & & 235 & & & 354 & & 804 \\
\hline $0.2 \mathrm{~g} 2006^{4}$ & 2.1 & 33 & & 121 & & & 207 & & 579 \\
\hline $2013^{5}$ & 2.5 & 33 & & 131 & 3500 & 155 & 244 & & 733 \\
\hline \multicolumn{10}{|l|}{ Hayle } \\
\hline $1974-79^{1,3,4}$ & $0.1-0.5$ & $97-106$ & $0.7-3.4$ & $27-122$ & $962-1930$ & $13-38$ & $21-51$ & $0.8-2.9$ & $978-1560$ \\
\hline \multicolumn{10}{|c|}{ (b) Uncontaminated } \\
\hline \multicolumn{10}{|l|}{ Avon (Devon) } \\
\hline $1977^{2}$ & 1.0 & 23 & 0.5 & 84 & 541 & 36 & 23 & 0.3 & 683 \\
\hline \multicolumn{10}{|c|}{ Torridge (Devon) } \\
\hline $1980^{1,2}$ & $0.7-1.5$ & $18-37$ & $1.1-2.4$ & $17-41$ & $1360-1980$ & $43-54$ & $13-40$ & $0.5-0.8$ & $403-1210$ \\
\hline Typical $^{8}$ & $0.1-5$ & $10-30$ & $0.2-3$ & $9-60$ & & & $4-40$ & $0.1-1$ & $300-1000$ \\
\hline $\mathrm{High}^{8}$ & $10-300$ & $100-300$ & $5-45$ & $120-360$ & & & $100-1500$ & $5-15$ & $2000-5000$ \\
\hline
\end{tabular}

Sources: Luoma \& Bryan $(1978)^{1}$, Bryan et al. $(1980)^{2}$, Langston $(1980)^{3}$, Rainbow et al. (2011a) ${ }^{4}$, Kalman et al. $(2015)^{5}$, Bryan \& Uysal $(1978)^{6}$, Bryan \& Hummerstone $(1978)^{7}$, Rainbow $(2018)^{8}$.

H. diversicolor at the top of Restronguet Creek was shown to have developed tolerance for both copper and zinc (Bryan \& Hummerstone, 1971, 1973; Bryan \& Gibbs, 1983). Furthermore, it has been confirmed that this copper and zinc-tolerant population is still present in the 21 st century, substantiating the ongoing ecotoxicological significance of the very high copper and zinc bioavailabilities in the local sediments (Mouneyrac et al., 2003).

The copper and zinc tolerances of this population of $H$. diversicolor have been shown to be genetically based, and, therefore, inheritable down generations (Grant et al., 1989; Hateley et al., 1989). The metal tolerances do, however, come at a metabolic cost, bringing a competitive selective disadvantage beneath threshold sediment concentrations, estimated to be $1000 \mu \mathrm{gg}^{-1}$ copper and $3500 \mu \mathrm{g}^{-1}$ zinc (Grant et al., 1989;
Hateley et al., 1989). The metabolic costs of the metal tolerance in this upper Restronguet Creek worm population, based on increased rates of storage detoxification of copper and zinc (Berthet et al., 2003; Mouneyrac et al., 2003), result in a scope for growth $46-62 \%$ lower than that of non-tolerant worm populations (Pook et al., 2009). The considerable physiological cost of metal tolerance to this ragworm population is, correspondingly, only worth paying when copper and/or zinc exposure is ecotoxicologically significant (Pook et al., 2009).

In the 1970s and 1980s the local populations of other members of the flora and fauna of Restronguet Creek also showed tolerance to one or both of copper and zinc, providing evidence that the local total bioavailability of each trace metal was of ecotoxicological significance (Luoma, 1977). Thus Restronguet Creek populations 
Table 4. Mean, weight-standardized estimate ( $0.03 \mathrm{~g}$ worm), range of concentrations, or range of mean concentrations ( $\mu$ g $\mathrm{g}^{-1} \mathrm{dry}$ weight) of trace metals in the ragworm Hediste diversicolor (after depuration of gut contents) from south-west British estuaries (a) affected by mining contamination or (b) considered uncontaminated

\begin{tabular}{|c|c|c|c|c|c|c|c|c|c|}
\hline & $\mathrm{Ag}$ & As & $\mathrm{Cd}$ & $\mathrm{Cu}$ & $\mathrm{Fe}$ & $\mathrm{Mn}$ & $\mathrm{Pb}$ & Sn & $\mathrm{Zn}$ \\
\hline \multicolumn{10}{|l|}{ (a) Mining } \\
\hline \multicolumn{10}{|c|}{ Restronguet Creek } \\
\hline$\sim 1970-72^{1,2}$ & & & $0.33-1.1$ & 1140 & 425 & 6.0 & 3.5 & & $194-225$ \\
\hline $1977-78^{3,4}$ & $3.0-6.2$ & $23-87$ & $0.53-1.8$ & $832-1430$ & $268-554$ & $8.3-14$ & $1.9-9.8$ & $0.2-0.5$ & $262-405$ \\
\hline $2002^{5,6}$ & & & 1.3 & 2630 & & & & & 278 \\
\hline $0.03{\mathrm{~g} 2003^{7}}^{7}$ & 1.4 & 90 & & 614 & & & 2.5 & & 194 \\
\hline $0.03{\mathrm{~g} 2006^{7}}^{7}$ & 2.0 & 56 & & 457 & & & & & 179 \\
\hline $2007^{8,9}$ & 4.8 & & $<1.0-2.3$ & 3850 & & & & & 1930 \\
\hline \multicolumn{10}{|l|}{ Tamar } \\
\hline$\sim 1970-72^{1,2}$ & & & 0.85 & 106 & 458 & 11 & 5.8 & & $160-166$ \\
\hline $1974^{3,10}$ & $0.6-0.8$ & 13 & $0.27-0.53$ & $46-130$ & $377-591$ & $6.9-13$ & $5.2-7.0$ & $0.1-0.3$ & $163-179$ \\
\hline $1974-80^{4}$ & $0.8-1.2$ & & $0.27-0.65$ & $133-236$ & & & & & \\
\hline \multicolumn{10}{|l|}{ Tavy } \\
\hline $1974-80^{4,10}$ & $1.7-2.6$ & 17 & $1.3-2.7$ & 204-218 & 484 & 12 & 31 & 0.2 & 207 \\
\hline $0.03{\mathrm{~g} 2003^{7}}^{7}$ & 1.2 & 10 & & 43 & & & 2 & & 157 \\
\hline $0.03{\mathrm{~g} 2006^{7}}^{7}$ & 0.7 & 13 & & 40 & & & & & 170 \\
\hline $2007^{8,9}$ & 1.3 & & 2.6 & 214 & & & & & 472 \\
\hline \multicolumn{10}{|l|}{ Gannel } \\
\hline$\sim 1972^{2}$ & & & $1.7-2.4$ & & & & & & $153-312$ \\
\hline $1974-80^{4,10}$ & $1.9-5.3$ & 21 & $0.37-1.5$ & $67-257$ & $349-431$ & $11-16$ & $13-685$ & 1.3 & $222-466$ \\
\hline 0.03 g $2003^{7}$ & 1.5 & 20 & & 67 & & & 29 & & 197 \\
\hline $0.03{\mathrm{~g} 2006^{7}}^{7}$ & 0.7 & 23 & & 61 & & & & & 236 \\
\hline \multicolumn{10}{|l|}{ West Looe } \\
\hline$\sim 1972^{2}$ & & & 0.27 & & & & & & 155 \\
\hline $1974-80^{4,10}$ & $1.0-1.1$ & 20 & $0.20-0.41$ & $29-55$ & 399 & 12 & 26 & 0.5 & 257 \\
\hline $0.03{\mathrm{~g} 2003^{7}}^{7}$ & 0.5 & 13 & & 27 & & & 37 & & 140 \\
\hline $0.03{\mathrm{~g} 2006^{7}}^{7}$ & 1.0 & 13 & & 30 & & & & & 177 \\
\hline \multicolumn{10}{|l|}{ Hayle } \\
\hline $1974^{3}$ & 5.3 & 84 & 0.47 & 1210 & 734 & 5.7 & 4.2 & 0.08 & 260 \\
\hline $1974-80^{4}$ & 8.0 & & 0.17 & 947 & & & & & \\
\hline \multicolumn{10}{|c|}{ (b) Uncontaminated } \\
\hline \multicolumn{10}{|l|}{ Avon (Devon) } \\
\hline$\sim 1970-72^{1,2}$ & & & 0.15 & 33 & 391 & 9.8 & 3.4 & & $150-176$ \\
\hline $1977^{3,10}$ & 0.1 & 8 & 0.14 & 19 & 564 & 12 & 5.4 & 0.09 & 197 \\
\hline \multicolumn{10}{|c|}{ Torridge (Devon) } \\
\hline$\sim 1972^{2}$ & & & 0.08 & & & & & & 155 \\
\hline $1980^{3,10}$ & 0.3 & $13-14$ & $0.22-0.44$ & $20-21$ & $532-604$ & $14-16$ & $0.2-2.0$ & $0.09-0.1$ & $163-183$ \\
\hline Typical $^{11}$ & $0.1-1.0$ & $6-10$ & $0.05-1.0$ & $10-30$ & & & $0.2-5$ & $0.04-0.3$ & $100-300$ \\
\hline High $^{11}$ & $3-40$ & $20-250$ & $2.5-10$ & $50-4000$ & & & $10-1000$ & $0.5-3$ & $400-2000$ \\
\hline
\end{tabular}

Sources: Bryan \& Hummerstone $(1971)^{1}$, Bryan \& Hummerstone $(1973)^{2}$, Bryan \& Gibbs $(1983)^{3}$, Luoma \& Bryan $(1982)^{4}$, Rainbow et al. (2004) ${ }^{5}$, Geffard et al. $(2005)^{6}$, Rainbow et al. $(2011 a)^{7}$, Rainbow et al. $(2009 a)^{8}$, Rainbow et al. $(2009 b)^{9}$, Bryan et al. $(1980)^{10}$, Rainbow $(2018)^{11}$.

of the predatory polychaete worm Nephtys hombergii, the deposit-feeding amphipod crustacean Corophium volutator and the omnivorous shore crab Carcinus maenas were all shown to be tolerant of raised bioavailabilities of copper (Bryan \& Gibbs, 1983). As for the $H$. diversicolor population, the Restronguet
Creek population of C. maenas was also tolerant of raised zinc bioavailabilities (Bryan \& Gibbs, 1983).

In the case of the shore crab Carcinus maenas, small crabs below $3 \mathrm{~cm}$ carapace width are not uncommon in the lower and middle reaches of the Creek, and larger crabs can be found higher 
in the estuary during the summer (Bryan \& Gibbs, 1983). Small crabs below $1 \mathrm{~g}$ wet weight in Restronguet Creek have particularly high total concentrations of both copper and zinc, while larger crabs (about $50 \mathrm{~g}$ wet weight) have total concentrations of these trace metals that are lower but still raised on a national scale (Bryan \& Gibbs, 1983). Thus decreased rates of copper and zinc uptake and accumulation may be part of the mechanisms of tolerance by Restronguet Creek crabs for each of these two trace metals (Bryan \& Gibbs, 1983).

Shore crabs have a planktonic larval stage, the zoea, which drifts for several weeks in surface coastal waters. Therefore, the individual crabs making up the Restronguet Creek population would have originated from parents almost certainly living outside the Creek. These parent crabs would not have been under any selective pressure to evolve either copper or zinc tolerance. Thus any copper or zinc tolerance would have been selected for in individual crabs settling in, or migrating into, Restronguet Creek, be it brought about by decreased uptake from water and/ or diet, by increased excretion, by increased storage detoxification, or by any combination of these processes (Rainbow, 2018). Thus there is likely to be no single population-wide physiological mechanism for tolerance in these Restronguet Creek shore crabs, as might be the case, for example, for the local copper-tolerant population of the amphipod Corophium volutator which broods its young and lacks a planktonic dispersal phase in the life cycle. In fact a study in 1996 and 1997 found that the shore crabs then present in Restronguet Creek did not have significantly lower uptake rates from solution of zinc (nor of cadmium or silver) than crabs from Millport in the Firth of Clyde (Rainbow et al., 1999).

\section{Meiofaunal community composition}

In addition to larger burrowing invertebrates such as ragworms, the sediments of estuaries are home to meiofauna, very small animals in the size range between $45 \mu \mathrm{m}$ and $1 \mathrm{~mm}$. Dominant members of the meiofauna of estuarine sediments are nematode worms and harpacticoid copepods.

A 1991 survey of the sediment meiofaunal communities in five creeks of the Fal Estuary system including Restronguet Creek, with different sediment concentrations of trace metals (especially copper), showed up a strong relationship between the meiofaunal nematode community structure and sediment trace metal concentrations (Somerfield et al., 1994). The nematodes were more responsive than the harpacticoid copepods to sediment trace metal concentrations, showing different community compositions, including lower generic richness and diversity, across the gradient of these metal concentrations in the different creeks (Somerfield et al., 1994). The harpacticoid copepods, on the other hand, only showed a difference in community composition in the highly trace metal-contaminated sediment of Restronguet Creek (Somerfield et al., 1994).

The application of PICT as an ecotoxicological tool (Blanck et al., 1988) is very appropriate at the size scale of meiofauna. A random selection of nematodes from Restronguet Creek were more tolerant of copper exposure than nematodes from Percuil Creek (Millward \& Grant, 1995; Grant \& Millward, 1997), the least trace metal contaminated of the Fal Estuary creeks in the previous study (Somerfield et al., 1994). The increase in community tolerance of Restronguet Creek nematodes results from the loss of sensitive species and the increased abundance of more copper-resistant nematode species, together, apparently, with selection for a copper-tolerant population in at least one nematode species (Grant \& Millward, 1997; Millward \& Grant, 2000). A species of nematode that appears relatively trace metalresistant is Tripyloides marinus, abundant in Restronguet Creek but also present in other creeks of the Fal Estuary, and throughout northern Europe (Millward, 1996). It is the Restronguet Creek population of T. marinus that has developed tolerance to copper (Millward, 1996). More detailed PICT observations showed that a successively weaker impact of copper exposure was also apparent in nematode communities from some of the moderately coppercontaminated sediments of other creeks in the Fal Estuary system, in the order Restronguet, Mylor, Pill and St Just (Grant \& Millward, 1997; Millward \& Grant, 2000). An expanded PICT study of copper tolerance in meiofaunal nematode communities in estuaries of south-west England indicated that a threshold sediment concentration of $200 \mu \mathrm{g} \mathrm{g}^{-1}$ copper is needed before selection for nematode community copper tolerance (Millward \& Grant, 2000).

\section{Microbial community composition}

PICT studies are also particularly appropriate for microbiological communities, including those in estuarine sediments. A study of the microbial community in the sediments of the Fal Estuary system including Restronguet Creek, the Hayle Estuary and a control site in the Kingsbridge Estuary, Devon, was carried out in 2002 to investigate the relationship between copper concentrations in sediment pore water and microbial activity (Ogilvie \& Grant, 2008). There was a clear dose-response relationship between the sediment concentration of copper and microbial community tolerance to copper exposure (Ogilvie \& Grant, 2008).

\section{Macroinvertebrate community composition}

The presence of metal-tolerant populations of local estuarine macroinvertebrates (albeit at a physiological cost) will reduce the negative changes in the presence and population abundance of these organisms to be expected at the community level as a direct ecotoxicological response. It is still likely that the energetic costs of tolerance will have an effect on the reproductive output of local trace metal-tolerant populations, with potential effects at the population level. This may affect the Restronguet Creek population of a brooder and local recruiter such as the amphipod Corophium volutator, with consequences for community structure. The same argument may also apply to other invertebrates lacking planktonic larval dispersal, as in the case of Hediste diversicolor (Bryan et al., 1987). The crab Carcinus maenas, on the other hand, has a long period of pelagic larval dispersal, and the parents of the Restronguet Creek crabs live elsewhere. It is unlikely, then, that any reduction in reproductive output of the Restronguet Creek population of crabs will have any effect on future recruitment, and therefore crab population levels in the Creek.

So, does Restronguet Creek show changes in community composition that might otherwise be expected in the absence of severe trace metal contamination? In fact, yes (Bryan \& Gibbs, 1983). A major difference is seen in the absence or low abundance of bivalve molluscs in Restronguet Creek (Bryan \& Gibbs, 1983). Bivalves have a planktonic larval dispersal phase, the veliger larva, ultimately succeeded by a pediveliger, the settlement stage. Restronguet Creek does lack the large populations of mussels Mytilus edulis, cockles Cerastoderma edule, Baltic tellins Macoma balthica and (to a smaller extent) peppery furrow shells Scrobicularia plana, otherwise to be expected in a noncontaminated estuary (Bryan \& Gibbs, 1983; Bryan et al., 1987). It is possibly during the act of settlement by the pediveliger in contact with the local metal-contaminated sediment that copper and/or zinc toxicity intervenes, halting larval recruitment and the establishment of an adult population (Bryan \& Gibbs, 1983).

The small gastropod Peringia (formerly Hydrobia) ulvae is also conspicuous by its absence from Restronguet Creek (Bryan \& 
Gibbs, 1983). This snail may be affected by raised concentrations of dissolved trace metals in the surface waters of the Creek (Bryan \& Gibbs, 1983), or by high trace metal concentrations in the sediments with which it is in contact. In spite of the presence in Restronguet Creek in the 1970s and early 1980s of a coppertolerant population of the burrowing amphipod Corophium volutator (Bryan \& Gibbs, 1983), sampling in the early 1990s found this amphipod to be all but absent from Restronguet Creek (Warwick, 2001). Also absent was the carnivorous isopod crustacean Cyathura carinata. These two crustaceans would be expected to be present in some abundance in the absence of trace metal contamination (Warwick, 2001).

Restronguet Creek may no longer have the very high dissolved trace metal bioavailabilities of the past but it does still have exorbitantly high sediment bioavailabilities capable of eliciting ecotoxic effects. Copper and zinc are clearly two such ecotoxicological drivers in Cornish estuaries, although arsenic too may be of significance. Many toxic metal studies carried out in Cornwall in the 20th century used atomic absorption spectrophotometry (AAS) to measure concentrations of trace metals such as cadmium, copper, lead and zinc in physical and biological matrices. Measurement of arsenic is, however, not straightforward using AAS, necessitating a preliminary step to generate the hydride of arsenic before spectrophotometric measurements can be taken. Thus it was relatively rare then for arsenic to be measured in samples for trace metal analysis. Consequently any ecotoxicological role for the high bioavailabilities of arsenic in Cornish estuarine sediments may have been missed. Today, much analysis of trace metals in biological material is carried out by inductively coupled plasma (ICP) spectrometry (Woods \& McCurdy, 2012), measuring concentrations of arsenic simultaneously with those of many other metals. Correspondingly, in recent years there has been an increase in the number of metal ecotoxicology studies involving arsenic.

But what of the other trace metal-contaminated estuaries under consideration here? None has received the ecotoxicological attention of Restronguet Creek, although the persisting high trace metal bioavailabilities in their sediments do suggest that they are worthy of further ecotoxicological research.

In the 1970s and the first decade of the 21st century, the Tamar/Tavy Estuary system showed high bioavailabilities of lead and zinc, and to a lesser extent copper, to Scrobicularia plana (Table 3), corresponding to raised sediment concentrations of these trace metals at both sampling periods (Table 1). While S. plana monitors trace metal bioavailabilities in water and sediment, another biomonitor, Hediste diversicolor, responds mostly to sediment bioavailabilities alone. Raised sediment bioavailabilities to the ragworm of copper (particularly) and to a lesser extent arsenic, lead and zinc persist into this century in the Tavy Estuary (Table 4). Thus the Tamar/Tavy Estuary system can be considered today to offer somewhat raised sediment bioavailabilities of these trace metals to the local fauna.

Gannel Estuary sediments still have extremely high concentrations of lead and zinc, and to a lesser extent silver (Table 1). Although the bioavailabilities of lead and zinc to Scrobicularia plana are not quite as high in the 21st century as in the 1970s, they are still very high (Table 3 ). The decreases in these bioavailabilities over this period presumably reflect falls in dissolved bioavailabilities, given the importance of this source of metals to S. plana (Rainbow et al., 2011a; Rainbow, 2018). Similarly the sediment bioavailability of lead to $H$. diversicolor was, and is, high in the Gannel Estuary (Table 4) (Rainbow et al., 2011a). The sediments of the West Looe Estuary have high lead concentrations persisting from the 1970s into the 21st century (Table 1), reflected in ongoing high bioavailabilities to S. plana (Table 3) and H. diversicolor (Table 4) (Rainbow et al., 2011a).
Thus both the Gannel and West Looe Estuaries represent sites today with raised sediment bioavailabilities of lead. These sediments in fact offer a contrast in their physical parameters. The Gannel Estuary on the north Cornish coast is open to wave exposure and the sediments are relatively sandy. The West Looe Estuary on the south coast, on the other hand, is very sheltered and the estuarine sediments take the form of extensive flats of fine mud.

The sediments of the Hayle Estuary still have very high concentrations of arsenic and copper, and also of lead and zinc (Table 1). Sediment bioavailabilities of copper, arsenic and probably zinc to $H$. diversicolor were high in the Hayle Estuary in the 1970s and 1980s (Table 4). The local Hayle Estuary population of Hediste diversicolor was shown to exhibit copper tolerance in the 1970s (Bryan, 1976). Given the predominance of the ingested sediment route of trace metal uptake in this ragworm, the conclusion is that the bioavailability of the sediment-associated copper in the Hayle Estuary then was of ecotoxicological significance. Given the lack of decrease in sediment copper concentrations there into the 21 st century (Table 1), it is likely that this ecotoxicologically significant high sediment copper bioavailability remains today.

High sediment bioavailabilities of toxic metals will have a direct effect on the infauna, particularly invertebrates such as Hediste diversicolor which ingest the sediments. But what about animals higher in the food chain that may feed on such invertebrates with their high metal loadings? These predators would include fish such as the flounder Platichthys flesus at high tide and waders such as the redshank Tringa totanus at low tide. While such predators may well ingest considerable loads of dietary trace metals, they may not necessarily have the digestive strength to break down the detoxified storage forms of the trace metals accumulated in their prey so releasing them for subsequent alimentary uptake (Rainbow et al., 2011b). Furthermore, even if the predator can digest and take up the high dietary load of toxic metals, they may in turn have an appropriate physiology to cope with this high metal load, be it by their own methods of detoxified storage or by excretion (Rainbow, 2018).

Flounders at the top of Restronguet Creek feed on the ragworm $H$. diversicolor with their huge accumulated concentrations of copper and occasionally high concentrations of zinc (Table 4). Yet such flounders showed little evidence of extra copper or zinc in their tissues other than some enhancement of copper concentrations in the viscera (Bryan \& Gibbs, 1983). It would appear, therefore, that the trace metals are not being taken up from the diet and/or that they are being excreted after absorption by the flounder (Bryan \& Gibbs, 1983). Experiments with another fish, the gurnard Trigla lucerna, fed with these same ragworms suggested that the copper in the ragworms was passing through the gut of the fish without assimilation (Bryan \& Gibbs, 1983).

Visiting redshank in Restronguet Creek feed on the same copper-rich H. diversicolor (Bryan \& Langston, 1992). While copper concentrations in the ragworms are up to two orders of magnitude above normal (Table 4), the livers of the Restronguet Creek redshank contained about $30 \mu \mathrm{g} \mathrm{g}^{-1}$ copper, only about 1.5 times the control level (Bryan \& Langston, 1992). Thus the waders are retaining only a very small proportion of the copper ingested. This very small retention $(\sim 1 \%)$ by waders of ingested trace metals also extends to other trace metals (for example lead and zinc) and other waders (for example curlews Numenius arquata and dunlin Calidris alpina) (Evans et al., 1987). In contrast to the flounder, the waders do appear to be assimilating the dietary trace metals and are subsequently excreting the great majority of the trace metals taken up (Evans et al., 1987). The excretion of the excess copper assimilated by the Restronguet Creek redshank may or may not have a significant energetic cost, with potential ecotoxicological consequences (Bryan \& Langston, 1992). 


\section{Conclusions}

In spite of the cessation of most significant mining in the river catchments of Cornwall more than a century ago, there remain today certain Cornish estuaries with extremely high sediment concentrations of toxic trace metals, particularly copper and arsenic, but also lead and zinc. These high trace metal loadings in the sediments are to a large degree bioavailable to the local infauna, especially those invertebrates ingesting the sediment. Furthermore some of these sediment trace metal bioavailabilities are so high as to be of ecotoxicological concern, with deleterious effects on the local biota at levels of biological organization up to and including changed community structure.

Yet life survives in these estuaries, and the surviving organisms offer a tremendous resource for researchers into comparative physiological mechanisms of trace metal ecophysiology and ecotoxicology, and the ecological consequences of an ecotoxicological stressor on a biological community, in this case estuarine communities. These estuaries are especially attractive field sites for research since they in effect lack the confounding presence of other anthropogenic contaminants inevitably present in most estuaries in the developed world. The estuaries also offer a range of combinations of different trace metals and a comparative gradient of sediment bioavailabilities of these trace metals.

Restronguet Creek and particularly the local resident populations of the ragworm Hediste diversicolor have already been exploited for such comparative research, but there is more potential available both in this estuary and in the comparative range offered by the other estuaries discussed above. For example these ragworms have provided insight into comparative methods of trace metal detoxification (Berthet et al., 2003; Mouneyrac et al., 2003), into the comparative biodynamic modelling of trace metal bioaccumulation (Rainbow et al., 2009a), into the trophic transfer of trace metals to invertebrate (Rainbow et al., 2004, 2006) and vertebrate predators (Bryan \& Gibbs, 1983), and into the development (Grant et al., 1989) and energetic cost of trace metal tolerance (Pook et al., 2009).

The trace metal-contaminated estuaries of Cornwall represent a unique comparative series of field research sites for ecotoxicological research. Potential areas of research include comparative omics (especially the genomics, proteomics, transcriptomics and metabolomics) of trace metal accumulation and detoxification by macroinvertebrates, the environmental genomics of microbes and meiofauna, the testing of methods of comparative community analyses at molecular and organism levels, and cost-benefit analyses of the selection of trace-metal tolerant populations.

\section{References}

Amiard JC, Amiard-Triquet C and Métayer C (1985) Experimental study of bioaccumulation, toxicity and regulation of some trace metals in various estuarine and coastal organisms. Symposia Biologica Hungarica 29, 313-323.

Atkinson RL (1985) Tin and Tin Mining. Princes Risborough: Shire Publications.

Atkinson RL (1987) Copper and Copper Mining. Princes Risborough: Shire Publications.

Barton DB (1971) Arsenic production in West Cornwall. In Barton DB (ed.), Essays in Cornish Mining History, vol. 2. Truro: D. Bradford Barton, pp. 101-125.

Beane SJ, Comber SDW, Rieuwerts J and Long P (2016) Abandoned metal mines and their impact on receiving waters: a case study from southwest England. Chemosphere 153, 294-306.

Benedetti M, Ciaprini F, Piva F, Onorati F, Fattorini D, Notti A, Ausili A and Regoli F (2011) A multidisciplinary weight of evidence approach for classifying polluted sediments: integrating sediment chemistry, bioavailability, biomarkers responses and bioassays. Environment International 38, 17-28.

Berthet B, Mouneyrac C, Amiard J-C, Amiard-Triquet C, Berthelot Y, Le Hen A, Mastain O, Rainbow PS and Smith BD (2003) Accumulation and soluble binding of cadmium, copper, and zinc in the polychaete Hediste diversicolor from coastal sites with different trace metal bioavailabilities. Archives of Contamination and Toxicology 45, 468-478.

Blanck H, Wängberg SA and Molander S (1988) Pollution-induced community tolerance - a new ecotoxicological tool. In Cairns J and Pratt JR (eds), Functional Testing of Aquatic Biota for Estimating Hazards of Chemicals ASTM 988. Philadelphia, PA: American Society for Testing and Materials, pp. 219-230.

Bowman JA (1968) The determination of tin in tin ores and concentrates by atomic absorption spectrophotometry in the nitrous-oxide acetylene flame. Analytica Chimica Acta 42, 285-291.

Bryan GW (1976) Some aspects of heavy metal tolerance in aquatic organisms. In Lockwood APM (ed.), Effects of Pollutants on Aquatic Organisms. Cambridge: Cambridge University Press, pp. 7-34.

Bryan GW (1984) Pollution due to heavy metals and their compounds. In Kinne O (ed.), Marine Ecology, Part 3. London: John Wiley \& Sons, pp. 1289-1430.

Bryan GW and Hummerstone LG (1971) Adaptation of the polychaete Nereis diversicolor to estuarine sediments containing high concentrations of heavy metals. 1. General observations and adaptations to copper. Journal of the Marine Biological Association of the United Kingdom 51, 845-863.

Bryan GW and Hummerstone LG (1973) Adaptation of the polychaete Nereis diversicolor to estuarine sediments containing high concentrations of zinc and cadmium. Journal of the Marine Biological Association of the United Kingdom 53, 839-857.

Bryan GW and Hummerstone LG (1977) Indicators of heavy-metal contamination in the Looe Estuary (Cornwall) with particular regard to silver and lead. Journal of the Marine Biological Association of the United Kingdom 57, 75-92.

Bryan GW and Hummerstone LG (1978) Heavy metals in the burrowing bivalve Scrobicularia plana from contaminated and uncontaminated estuaries. Journal of the Marine Biological Association of the United Kingdom 58, 401-419.

Bryan GW and Uysal H (1978) Heavy metals in the burrowing bivalve Scribicularia plana from the Tamar estuary in relation to environmental levels. Journal of the Marine Biological Association of the United Kingdom 58, 89-108.

Bryan GW and Gibbs PE (1983) Heavy metals in the Fal Estuary, Cornwall: a study of long-term contamination by mining waste and its effects on estuarine organisms. Occasional Publications of the Marine Biological Association of the United Kingdom 2, 1-112.

Bryan GW and Langston WJ (1992) Bioavailability, accumulation and effects of heavy metals in sediments with special reference to United Kingdom estuaries: a review. Environmental Pollution 76, 89-131.

Bryan GW, Langston WJ and Hummerstone LG (1980) The use of biological indicators of heavy metal contamination in estuaries. Occasional Publications of the Marine Biological Association of the United Kingdom 1, 1-73.

Bryan GW, Langston WJ, Hummerstone LG and Burt GR (1985) A guide to the assessment of heavy-metal contamination in estuaries. Occasional Publications of the Marine Biological Association of the United Kingdom 4, 1-92.

Bryan GW, Gibbs PE, Hummerstone LG and Burt GR (1987) Copper, zinc, and organotin as long-term factors governing the distribution of organisms in the Fal Estuary in southwest England. Estuaries 10, 208-219.

Buckley JA (1992) The Cornish Mining Industry: A Brief History. Redruth: Tor Mark Press.

Burt R, Waite P and Burnley R (1987) Cornish Mines: Metalliferous and Associated Minerals 1845-1913. Exeter: University of Exeter in association with The Northern Mine Research Society NMRA, Wheaton and Co.

Chapman PM (2007) Determining when contamination is pollution - weight of evidence determinations for sediments and effluents. Environment International 33, 492-501.

Clements WH and Rohr JR (2009) Community responses to contaminants: using basic ecological principles to predict ecotoxicological effects. Environmental Toxicology and Chemistry 28, 1789-1800.

Dines HG (1969) The Metalliferous Mining Region of South-West England. Volumes I and II. 2nd impression with amendments. London: Her Majesty's Stationery Office.

Dorrington VH and Pyatt FB (1982) History, ecology and physical and chemical nature of two metalliferous spoil tips in south-west England. International Journal of Environmental Studies 18, 177-185.

Evans PR, Uttley JD, Davidson NC and Ward P (1987) Shorebirds (S.Os Charadrii and Scolopaci) as agents of transfer of heavy metals within and 
between estuarine ecosystems. In Coughtrey PJ, Martin MH and Unsworth MS (eds), Pollutant Transport and Fate in Ecosystems. Special Publication Number 6 of the British Ecological Society. Oxford: Blackwell Scientific Publications, pp. 337-352.

Geffard A, Smith BD, Amiard-Triquet C, Jeantet AY and Rainbow PS (2005) Kinetics of trace metal accumulation and excretion in the polychaete Nereis diversicolor. Marine Biology 147, 1291-1304.

Grant A and Millward RN (1997) Detecting community responses to pollution. In Hawkins LE, Hutchinson S, Jensen AC, Sheader M and Williams JA (eds), Responses of Marine Organisms to Their Environment. Proceedings of the $30^{\text {th }}$ European Marine Biology Symposium. Southampton: Southampton Oceanography Centre, University of Southampton, pp. 201-209.

Grant A, Hateley JG and Jones NV (1989) Mapping the ecological impact of heavy metals in the estuarine polychaete Nereis diversicolor using inherited metal tolerance. Marine Pollution Bulletin 20, 235-238.

Hateley JG, Grant A and Jones NV (1989) Heavy metal tolerance in estuarine populations of Nereis diversicolor. In Ryland JS and Tyler PA (eds), Reproduction, Genetics and Distribution of Marine Organisms, Proceedings 23rd European Marine Biological Symposium. Fredensborg: Olsen and Olsen, pp. 379-385.

Kalman J, Smith BD, Bury NR and Rainbow PS (2014) Biodynamic modelling of the bioaccumulation of trace metals by an infaunal estuarine invertebrate, the clam Scrobicularia plana. Aquatic Toxicology 154, 121-130.

Kalman J, Bonnail-Miguel E, Smith BD, Bury NR and Rainbow PS (2015) Toxicity and the fractional distribution of trace metals accumulated from contaminated sediments by the clam Scrobicularia plana exposed in the laboratory and the field. Science of the Total Environment 506-507, 109-117.

Klumpp DW and Peterson PJ (1979) Arsenic and other trace elements in the waters and organisms of an estuary in SW England. Environmental Pollution 19, 11-20.

Langston WJ (1980) Arsenic in UK estuarine sediments and its availability to benthic organisms. Journal of the Marine Biological Association of the United Kingdom 60, 869-881.

Langston WJ (1983) The behaviour of arsenic in selected United Kingdom estuaries. Canadian Journal of Fisheries and Aquatic Sciences 40(suppl. 2), 143-150.

Langston WJ (1984) Availability of arsenic to estuarine and marine organisms: a field and laboratory evaluation. Marine Biology 80, 143-154.

Luoma SN (1977) Detection of trace contaminant effects in aquatic ecosystems. Journal of the Fisheries Research Board of Canada 34, 436-439.

Luoma SN and Bryan GW (1978) Factors controlling the availability of sediment-bound lead to the estuarine bivalve Scrobicularia plana. Journal of the Marine Biological Association of the United Kingdom 58, 793-802.

Luoma SN and Bryan GW (1982) A statistical study of environmental factors controlling concentrations of heavy metals in the burrowing bivalve Scrobicularia plana and the polychaete Nereis diversicolor. Estuarine, Coastal and Shelf Science 15, 95-108.

Millward RN (1996) Intracellular inclusions in the nematode Tripyloides marinus from metal-enriched and cleaner estuaries in Cornwall, south-west England. Journal of the Marine Biological Association of the United Kingdom 76, 885-895.

Millward RN and Grant A (1995) Assessing the impact of copper on nematode communities from a chronically metal-enriched estuary using pollution-induced community tolerance. Marine Pollution Bulletin 30, 701-706.

Millward RN and Grant A (2000) Pollution-induced tolerance to copper of nematode communities in the severely contaminated Restronguet Creek and adjacent estuaries, Cornwall, United Kingdom. Environmental Toxicology and Chemistry 19, 454-461.

Mouneyrac C, Mastain O, Amiard J-C, Amiard-Triquet C, Beaunier P, Jeantet A-Y, Smith BD and Rainbow PS (2003) Trace-metal detoxification and tolerance of the estuarine worm Hediste diversicolor chronically exposed in their environment. Marine Biology 143, 731-744.

Ogilvie L and Grant A (2008) Linking pollution induced community tolerance (PICT) and microbial community structure in chronically metal polluted estuarine sediments. Marine Environmental Research 65, 187-198.

Perkins JW (1972) Geology Explained: Dartmoor and the Tamar Valley. Newton Abbot: David and Charles.

Pook C, Lewis C and Galloway T (2009) The metabolic and fitness costs associated with metal resistance in Nereis diversicolor. Marine Pollution Bulletin 58, 1063-1071.

Rainbow PS (2018) Trace Metals in the Environment and Living Organisms. The British Isles as a Case Study. Cambridge: Cambridge University Press.

Rainbow PS, Amiard-Triquet C, Amiard JC, Smith BD, Best SL, Nassiri Y and Langston WJ (1999) Trace metal uptake rates in crustaceans (amphipods and crabs) from coastal sites in NW Europe differentially enriched with trace metals. Marine Ecology Progress Series 183, 189-203.

Rainbow PS, Geffard A, Jeantet A-Y, Smith BD, Amiard JC and Amiard-Triquet C (2004) Enhanced food chain transfer of copper from a diet of copper-tolerant estuarine worms. Marine Ecology Progress Series 271, 183-191.

Rainbow PS, Poirier L, Smith BD, Brix KV and Luoma SN (2006) Trophic transfer of trace metals from the polychaete worm Nereis diversicolor to the polychaete Nereis virens and the decapod crustacean Palaemonetes varians. Marine Ecology Progress Series 321, 167-181.

Rainbow PS, Smith BD and Luoma SN (2009a) Differences in trace metal bioaccumulation kinetics among populations of the polychaete Nereis diversicolor from metal-contaminated estuaries. Marine Ecology Progress Series 376, 173-184.

Rainbow PS, Smith BD and Luoma SN (2009b) Biodynamic modelling and the prediction of $\mathrm{Ag}, \mathrm{Cd}$ and $\mathrm{Zn}$ accumulation from solution and sediment by the polychaete Nereis diversicolor. Marine Ecology Progress Series 390, 145-155.

Rainbow PS, Kriefman S, Smith BD and Luoma SN (2011a) Have the bioavailabilities of trace metals to a suite of biomonitors changed over three decades in SW England estuaries historically affected by mining? Science of the Total Environment 409, 1589-1602.

Rainbow PS, Luoma SN and Wang W-X (2011b) Trophically available metal a variable feast. Environmental Pollution 159, 2347-2349.

Rainbow PS, Smith BD and Casado-Martinez MC (2011c) Biodynamic modelling of the bioaccumulation of arsenic by the polychaete Nereis diversicolor. Environmental Chemistry 8, 1-8.

Rollinson GK, Pirrie D, Power MR, Cundy A and Camm GS (2007) Geochemical and mineralogical record of historical mining, Hayle Estuary, Cornwall, UK. Geoscience in South-West England 11, 326-337.

Schweinsberg DP and Heffernan BJ (1970) Determination of tin in ores and concentrates. Talanta 17, 332-334.

Somerfield PJ, Gee JM and Warwick RM (1994) Soft sediment meiofaunal community structure in relation to a long-term heavy metal gradient in the Fal estuary system. Marine Ecology Progress Series 105, 79-88.

Warwick RM (2001) Evidence for the effects of metal contamination on the intertidal macrobenthic assemblages of the Fal Estuary. Marine Pollution Bulletin 42, 145-148.

Woods G and McCurdy E (2012) ICP-MS-MS delivers accurate trace-level arsenic analyses in complex samples. Spectroscopy 27, 18-29. 